\title{
Nucleophilic Addition to 2,3-Disubstituted Butanal Derivatives and Their Application to Natural Product Synthesis
}

\author{
Hidekazu HoRIE, Hideaki AKaike, Keisuke Kato, and Hiroyuki AKITA*,† \\ Faculty of Pharmaceutical Sciences, Toho University; 2-2-1 Miyama, Funabashi, Chiba 274-8510, Japan.
} Received July 14, 2010; accepted July 27, 2010; published online July 27, 2010

The reaction of 2,3-anti-2-tert-butyldimethylsiloxy-3-substituted butanal derivative [anti-B, ( \pm )-10 and ( \pm )16] derived from trans-(2,3)-epoxy butanoate (1) with carbon nucleophiles [ $\alpha$-furyl anion, acetate anion, and indium (In)-assisted allyl anion] has been investigated to give selectively the anti-, anti-adduct D. This anti-stereoselection could be explained by the Felkin-Anh transition state model. Thus obtained anti-, anti-adducts ( \pm )-17 and ( \pm$)$-38 were formally converted to natural products, $( \pm)$-asperlin $(2)$ and $( \pm)$-olivose (4), respectively. The major anti-, anti-adduct $( \pm)-26$ was converted to $( \pm)$-digitoxose $(3)$, while the minor anti-, syn-adduct $( \pm)$-27 was also converted to $( \pm)$-olivose (4). The reaction of $( \pm)-10$ with tert-butyl acetate anion gave predominantly afforded the anti-, anti-adduct $( \pm)-23$, which was converted to $( \pm)-1,5$-dideoxyhexitol $(25)$. Alternately, the reaction of 2,3-syn-2-tert-butyldimethylsiloxy-3-p-methoxyphenoxy butanal derivative $[s y n-\mathrm{B},( \pm)-14]$ derived from trans$(2,3)$-epoxy butanoate (1) with carbon nucleophile (In-assisted allyl anion) afforded a ca. $1: 1$ mixture of the syn-, anti-adduct $E[( \pm)-32$ or $( \pm)-34]$ and syn-, syn-adduct $F[( \pm)-33$ or $( \pm)-35]$. After separation of this mixture, $( \pm)-34$ and $( \pm)-35$ were separately converted to $( \pm)$-oliose $(5)$ and $( \pm)$-boivinose $(6)$, respectively.

Key words ( $( \pm)$-asperlin; $( \pm)$-digitoxose; $( \pm)$-olivose; $( \pm)$-oliose; $( \pm)$-boivinose; selective 1,2-anti-addition

Previously we reported the syntheses of natural products such as oudemansins, ${ }^{1}$ indolmycin, ${ }^{2}$ cystothiazoles, ${ }^{3)}$ and chuangxinmycin, ${ }^{4)}$ starting from trans-(2,3)-epoxy butanoate (1). In connection with these studies, the synthesis of 2,3anti-disubstituted butanal derivative anti-B (Chart 1) derived from (2,3)-anti-2-hydroxy ester anti-A and the synthesis of 2,3-syn-disubstituted butanal derivative syn-B (Chart 1) derived from (2,3)-syn-2-hydroxy ester syn-A aroused our interest. Nucleophilic addition of a carbanion to anti-B would give the building blocks $\mathbf{C}$ or $\mathbf{D}$ possessing three continuous chiral centers, while nucleophilic addition of carbanion to syn-B would afford the building blocks $\mathbf{E}$ or $\mathbf{F}$ possessing three continuous chiral centers as shown in Chart 1. These synthons could be converted to asperlin (2) exhibiting antitumour and antibacterial activity, and rare deoxysugar such as D-digitoxose (3), D-olivose (4), D-oliose (5) and D-boivinose (6). Rare monosaccharides are important structural constituents of numerous antibiotics. Herein we report the selective synthesis of the above-mentioned synthons $(\mathbf{C}, \mathbf{D}, \mathbf{E}$ and F) and their application to the synthesis of the above-men-

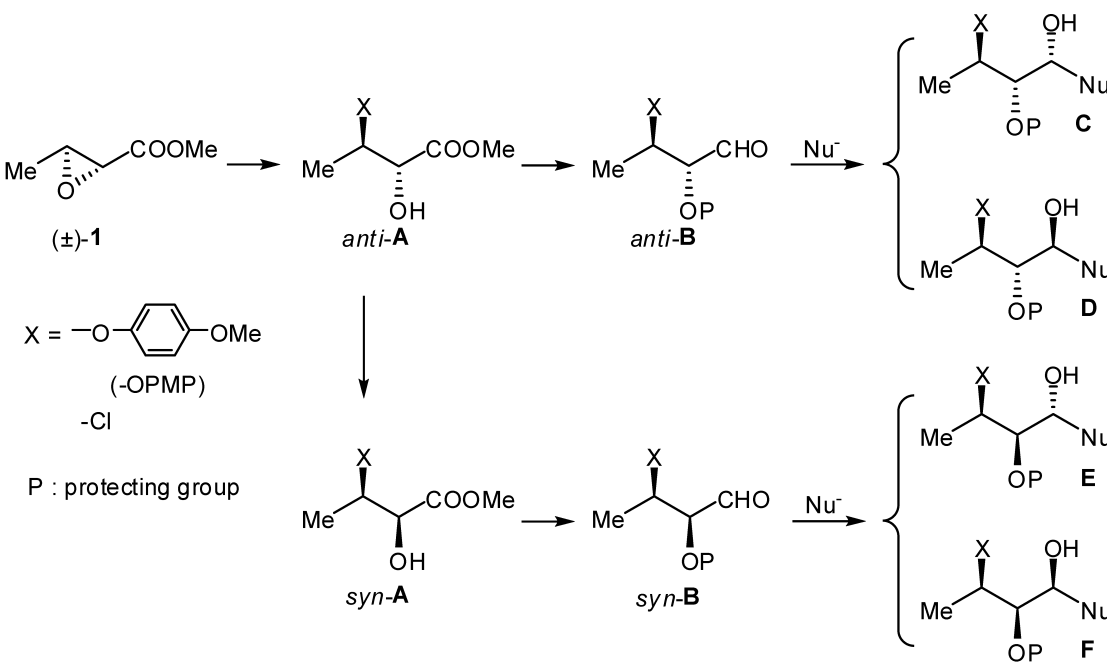<smiles>CO[C@H]1C=CC(=O)O[C@H]1C1OC1C</smiles>

(+)-Asperlin 2<smiles>C[C@H]1OC(O)C[C@@H](O)[C@@H]1O</smiles>

D-Digitoxose 3<smiles>[N][C@@H]1O[C@H](O)C[C@@H](O)[C@@H]1O</smiles><smiles>[C]C1OC(O)CC(O)C1O</smiles>

D-Oliose 5<smiles>C[C@H]1OC(O)C[C@@H](O)C1O</smiles>

D-Boivinose 6

\footnotetext{
${ }^{\dagger}$ Present address: Nihon Pharmaceutical University; 10281 Komuro, Inamachi, Kitaadachi-gun, Saitama 362-0806, Japan.
} 
tioned natural products.

Synthesis of $( \pm)-2,3-D i s u b s t i t u t e d$ Butanal Derivative (anti-B and syn-B) The staring $( \pm)$-2,3-anti-2-hydroxy-3p-methoxyphenoxybutanal (7) was previously obtained by the $\mathrm{BF}_{3} \cdot \mathrm{Et}_{2} \mathrm{O}$ assisted reaction of $( \pm)-\mathbf{1}$ and $p$-methoxyphenol. ${ }^{2)}$ Silylation of $( \pm)-7$ with tert-butyldimethylsilyl chloride (TBDMSCl) gave the corresponding silyl ether $( \pm)-8$ $(88 \%)$, which was reduced with diisobutylaluminum hydride (Dibal-H) to afford alcohol ( \pm )-9 in $77 \%$ yield. Pyridinium chlorochromate (PCC) oxidation of ( \pm )-9 gave the desired aldehyde $( \pm)-\mathbf{1 0}(75 \%)$ as shown in Chart 2. Alternately, the reaction of $( \pm)-7$ with benzoic acid in the presence of triphenylphosphine $\left(\mathrm{Ph}_{3} \mathrm{P}\right)$ and diisopropylazodicarboxylate gave (士)-2,3-syn-2-benzoloxy-3-p-methoxyphenoxybutanoate, which was subjected to hydrolysis to afford ( \pm )-2,3-syn-2hydroxy-3- $p$-methoxyphenoxybutanoate 11 (58\% yield). Thus obtained ( \pm )-11 was converted to 2,3-syn-disubstituted butanal derivative $( \pm)-\mathbf{1 4}$ in a similar manner as the synthesis of $( \pm)-\mathbf{1 0}[( \pm)-\mathbf{1 2}: 92 \%,( \pm)-\mathbf{1 3}: \mathbf{8 8 \%}$, and $( \pm)-\mathbf{1 4}$ : 79\%]. ( \pm )-3-Chloro-2-tert-butyldimethylsilyloxybutanal (16) was obtained by the reported procedure from $( \pm)-1 .{ }^{5}$

Formal Synthesis of ( \pm )-Asperlin (2) (+)-Asperlin (2), isolated from Aspergillus nidulans and Aspergillus caespiyosus, has been shown to exhibit antitumour and antibac- terial activity. Its structure, including the absolute configuration, was determined by spectroscopic and chemical studies. $^{6-8)}$ Because of its interesting bioactivity, the synthesis of natural product (2) and its related compounds has been reported by several groups. ${ }^{9-11)}$ The formal synthesis of $( \pm)$ asperlin (2) from $( \pm)-\mathbf{1 0}$ is shown in Chart 3. The reaction of ( \pm )-10 with $\alpha$-furyl anion gave major product $( \pm)-\mathbf{1 7}(77 \%$ yield) and minor product $( \pm)-\mathbf{1 8}$ (17\% yield). To confirm the stereochemistry of $( \pm)-\mathbf{1 7}$, it was converted to the known synthetic intermediate, epoxy-alcohol $( \pm)-22,{ }^{12,13)}$ for the synthesis of $( \pm)-2$. Protection of the secondary alcohol group of ( \pm )-17 as a benzoyl group followed by deprotection of the $p$-methoxyphenyl group with ceric ammonium nitrate (CAN) afforded ( \pm -20 (57\%). Tosylation of ( \pm )-20 gave the corresponding tosylate $( \pm)-21(86 \%)$, which was subjected to consecutive desilylation and $\mathrm{K}_{2} \mathrm{CO}_{3}$ treatment to afford epoxide $( \pm)-22$ in $61 \%$ yield. Spectral data $\left({ }^{1} \mathrm{H}-\right.$ and ${ }^{13} \mathrm{C}$-NMR) of the synthetic $( \pm)-22$ were identical with those of the reported $( \pm)-22 .{ }^{12)}$ The synthesis of $( \pm)$-asperlin (2) from $( \pm)-22$ was already achieved by Honda et al. ${ }^{12)}$ Consequently, the stereochemistry of $( \pm)-\mathbf{1 7}$ was determined to be 1,2-anti- and 2,3-anti-structures, and that of minor component ( \pm -18 was determined to be 1,2-syn- and 2,3-anti. The stereoselective formation of $( \pm)-\mathbf{1 7}$ from $( \pm)-\mathbf{1 0}$ is explained
$( \pm)-1$<smiles>[R2][C@H](C(=O)OC)[C@H](C)O[Na]</smiles>

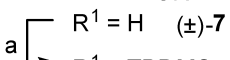

$\mathrm{a} \rightarrow \mathrm{R}^{1}=$ TBDMS $( \pm)-8$

$( \pm)-7$<smiles></smiles>

$a\left[\begin{array}{ll}R^{1}=H & ( \pm)-11\end{array}\right.$

$\mathrm{R}^{1}=$ TBDMS $( \pm)-12$

$( \pm)-1$<smiles>COC(=O)[C@H](O)[C@H](C)Cl</smiles>

$( \pm)-15$<smiles>C[13CH][13CH]</smiles>

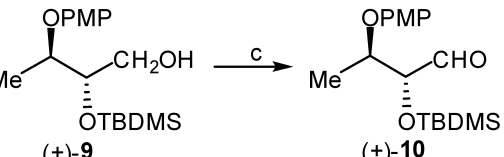

$( \pm)-10$

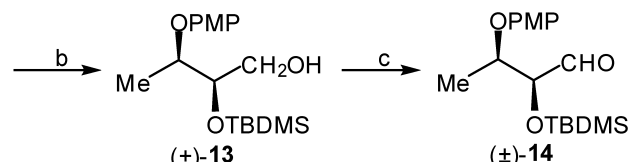

$( \pm)-13$

$( \pm)-14$

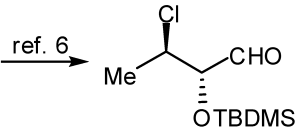

$( \pm)-16$
TBDMS : $-\mathrm{SiMe}_{2} \mathrm{Bu}^{t}$<smiles>C1CCCCC1</smiles>

Reagents: a; TBDMSCI / imidazole / DMF b; Dibal-H c; PCC d; 1) diisopropylazodicarboxylate $\left./ \mathrm{Ph}_{3} \mathrm{P} / \mathrm{PhCOOH} / \mathrm{THF} 2\right) \mathrm{K}_{2} \mathrm{CO}_{3} / \mathrm{MeOH}$

Chart 2

$( \pm)-10$

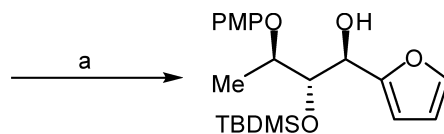

$( \pm)-17$

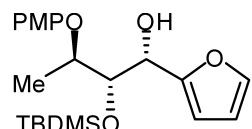

$( \pm)-18$ 
later in the text.

Synthesis of $( \pm)$-1,5-Dideoxyhexitol (25) The reaction of $( \pm)$-10 with tert-butyl acetate anion gave $\beta$-hydroxy ester $( \pm)-23(83 \%)$ as a single diastereoisomer as shown in Chart 4. To confirm the stereochemistry of $( \pm)-23$, it was converted to the known ( \pm )-1,5-dideoxyhexitol (25). ${ }^{14)}$ Reduction of ( \pm )-23 with $\mathrm{LiAlH}_{4}$ followed by consecutive desilylation and acetylation gave triacetate $( \pm)-24$ in $78 \%$ yield, which was subjected to consecutive desilylation and $\mathrm{K}_{2} \mathrm{CO}_{3}$ treatment to afford tetraol $( \pm)-25$ in $95 \%$ yield. Spectral data $\left({ }^{1} \mathrm{H}\right.$ - and $\left.{ }^{13} \mathrm{C}-\mathrm{NMR}\right)$ of the synthetic $( \pm)-25$ were identical with those of the reported $( \pm)-25 .{ }^{14)}$ Consequently, the stereochemistry of ( \pm )-25 was determined to be 3,4-anti- and 4,5anti. The stereoselective formation of $( \pm)-\mathbf{2 3}$ from $( \pm)-\mathbf{1 0}$ is explained later in the text.

Synthesis of ( \pm )-Digitoxose (3) and ( \pm )-Olivose (4) The metal indium (In) has recently been found to provide intriguing advantages for effecting carbon-carbon bond formation under aqueous condition. ${ }^{15,16)}$ The reaction of $( \pm)-\mathbf{1 0}$ with allyl bromide in the presence of In gave major product (士)-26 (86\% yield) and minor product $( \pm)-27$ (11\% yield) as shown in Chart 5. To confirm the stereochemistry of $( \pm)$ 26, it was converted to $( \pm)$-digitoxose (3). Deprotection of the silyl group of $( \pm)-26$ followed by acetylation afforded diacetate (土)-28 (74\%), which was subjected to consecutive deprotection of the $p$-methoxyphenyl group with CAN and $\mathrm{K}_{2} \mathrm{CO}_{3}$ treatment to afford triol $( \pm)-29$ in $73 \%$ yield. Ozonolysis of ( \pm )-29 followed by reductive treatment with dimethyl sulfide $\left(\mathrm{Me}_{2} \mathrm{~S}\right)$ afforded a 3.9:1 diastereomeric mixture $(\beta$-isomer : $\alpha$-isomer $=3.9: 1)$ of $( \pm)-3(73 \%)$. Spectral data $\left({ }^{1} \mathrm{H}\right.$ - and $\left.{ }^{13} \mathrm{C}-\mathrm{NMR}\right)$ of the synthetic $( \pm)-3$ were identical with those of the reported $( \pm)-3 .{ }^{17)}$ To confirm the stereochemistry of $( \pm)-27$, it was converted to $( \pm)$-olivose (4). Deprotection of the silyl group of $( \pm)-27$ followed by acetylation afforded diacetate $( \pm)-\mathbf{3 0}(76 \%)$, which was subjected to consecutive deprotection of the $p$-methoxyphenyl group with CAN and $\mathrm{K}_{2} \mathrm{CO}_{3}$ treatment to afford triol $( \pm)-31$ in $73 \%$ yield. Ozonolysis of $( \pm)-\mathbf{3 1}$ followed by reductive treatment with $\mathrm{Me}_{2} \mathrm{~S}$ afforded a $4: 3$ diastereomeric mixture $(\beta$ isomer: $\alpha$-isomer $=4: 3$ ) of $( \pm)$-olivose (4). Spectral data $\left({ }^{1} \mathrm{H}-\right.$ and $\left.{ }^{13} \mathrm{C}-\mathrm{NMR}\right)$ of the synthetic $( \pm)-4$ were identical with those of the reported $( \pm)-4 .{ }^{17)}$ Consequently, the stereochemistry of $( \pm)-26$ was determined to be 4,5-anti- and 5,6anti, and that of minor component ( \pm )-27 was determined to be 4,5-syn- and 5,6-anti. The stereoselective formation of $( \pm)-\mathbf{2 6}$ from $( \pm)-\mathbf{1 0}$ is explained later in the text.

Synthesis of $( \pm)$-Oliose (5) and $( \pm)$-Boivinose (6) The reaction of $( \pm)-\mathbf{1 4}$ with allyl bromide in the presence of In gave an inseparable 1.2:1 diastereomeric mixture of $( \pm)-32$ and ( \pm )-33 (99\% yield) as shown in Chart 6 . This mixture was subjected to consecutive deprotection of the silyl group and acetylation afforded the more polar diacetate $( \pm)-34$ (38\% in two steps) and the less polar diacetate $( \pm)-35(37 \%$ in two steps). The more polar diacetate $( \pm)-34$ was subjected to consecutive deprotection of the $p$-methoxyphenyl group with $\mathrm{CAN}$ and $\mathrm{K}_{2} \mathrm{CO}_{3}$ treatment to afford triol $( \pm)-36$ in $76 \%$ yield. Ozonolysis of ( \pm )-36 followed by reductive treatment with $\mathrm{Me}_{2} \mathrm{~S}$ afforded a 1:1 diastereomeric mixture of $( \pm)-5(66 \%)$. Spectral data $\left({ }^{1} \mathrm{H}-\right.$ and $\left.{ }^{13} \mathrm{C}-\mathrm{NMR}\right)$ of the synthetic $( \pm)-5$ were identical with those of the reported $( \pm)$ $5{ }^{17)}$ The less polar diacetate $( \pm)-35$ was subjected to consecutive deprotection of the $p$-methoxyphenyl group with CAN and $\mathrm{K}_{2} \mathrm{CO}_{3}$ treatment to afford triol $( \pm)-37$ in $78 \%$ yield. Ozonolysis of $( \pm)-37$ followed by reductive treatment with $\mathrm{Me}_{2} \mathrm{~S}$ afforded $c a$. $80 \% \beta$-anomer of $( \pm)-6(81 \%)$ with the reminder being a mixture of the $\alpha$-anomer and the furanose anomers. Spectral data $\left({ }^{1} \mathrm{H}-\right.$ and ${ }^{13} \mathrm{C}$-NMR) of the synthetic $( \pm)-6$ were identical with those of the reported $\left.( \pm)-6 .{ }^{17}\right)$ Consequently, the stereochemistry of the more polar $( \pm)-34$ was determined to be 4,5-anti- and 5,6-syn, and that of the

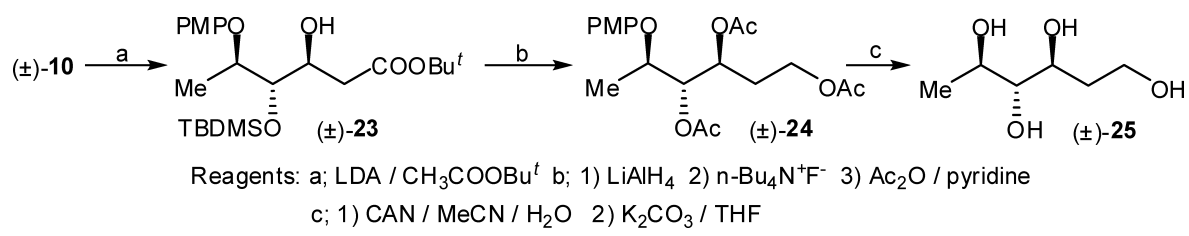

Chart 4

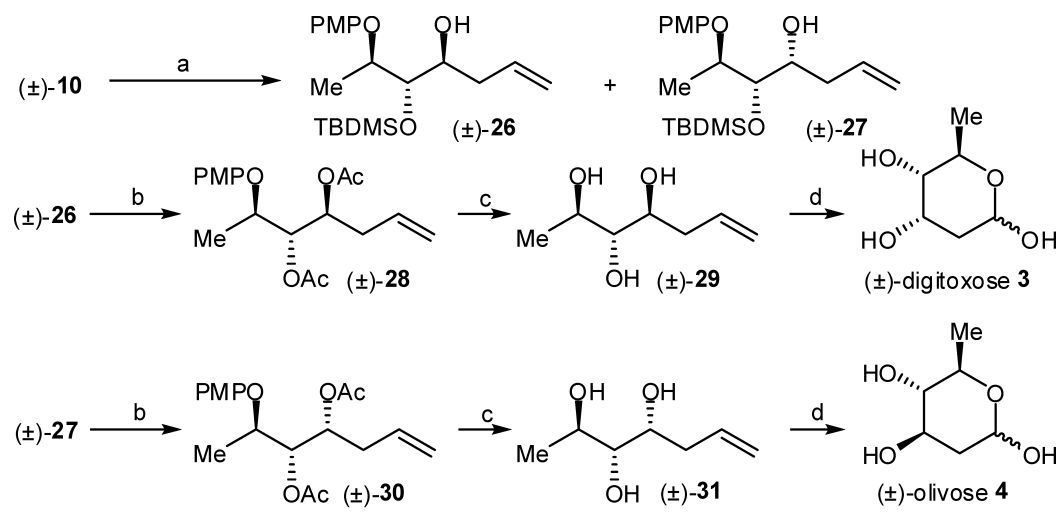

Reagents: a; In / allyl bromide / THF / $\mathrm{H}_{2} \mathrm{O}$ b; 1) $\mathrm{n}-\mathrm{Bu}_{4} \mathrm{~N}^{+} \mathrm{F}^{-}$2) $\mathrm{Ac}_{2} \mathrm{O} /$ pyridine

c; 1) $\mathrm{CAN} / \mathrm{MeCN} / \mathrm{H}_{2} \mathrm{O}$ 2) $\mathrm{K}_{2} \mathrm{CO}_{3} / \mathrm{THF}$ d; 1) $\mathrm{O}_{3}$ 2) $\mathrm{Me}_{2} \mathrm{~S}$ 
$( \pm)-14$
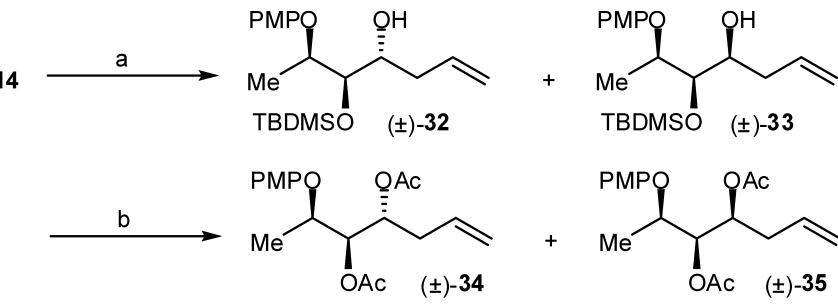

$( \pm)-34$

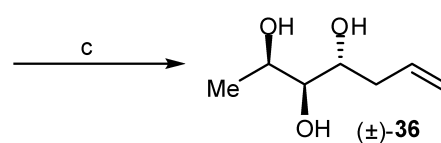

$( \pm)-35$

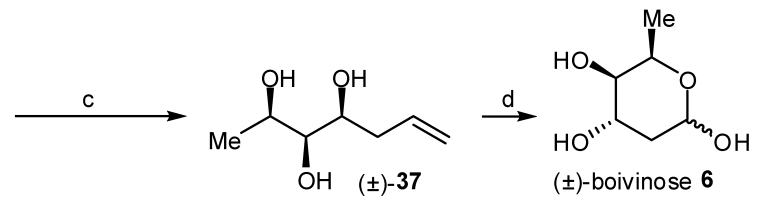

Reagents: a; In / allyl bromide / THF / $\mathrm{H}_{2} \mathrm{O}$ b; 1) $n-\mathrm{Bu}_{4} \mathrm{~N}^{+} \mathrm{F}^{-}$2) $\mathrm{Ac}_{2} \mathrm{O}$ / pyridine c; 1) $\mathrm{CAN} / \mathrm{MeCN} / \mathrm{H}_{2} \mathrm{O}$ 2) $\mathrm{K}_{2} \mathrm{CO}_{3} / \mathrm{THF}$ d; 1) $\mathrm{O}_{3}$ 2) $\mathrm{Me}_{2} \mathrm{~S}$

Chart 6

$( \pm)-16$

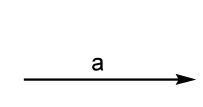

$\mathrm{M}$<smiles>C=CC[C@@H](O)[C@@H](OS(C)(=O)=O)[C@H](C)Cl</smiles><smiles>C=CC[C@@H](O)[C@@H](O[AsH3])[C@H](C)Cl</smiles>

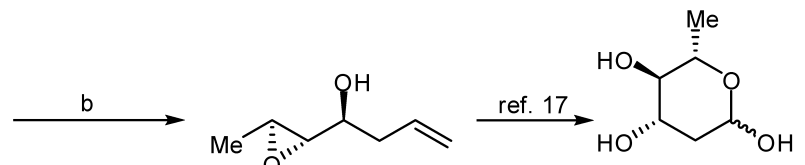

$( \pm)-40$

(士)-olivose 4

Reagents: a; In / allyl bromide / THF / $\mathrm{H}_{2} \mathrm{O}$ b; 1) Ethylvinylether / PPTS 2) $n-\mathrm{Bu}_{4} \mathrm{~N}^{+} \mathrm{F}^{-}$ 3) $\mathrm{K}_{2} \mathrm{CO}_{3}$ 4) $\mathrm{AcOH} / \mathrm{THF} / \mathrm{H}_{2} \mathrm{O}$

Chart 7

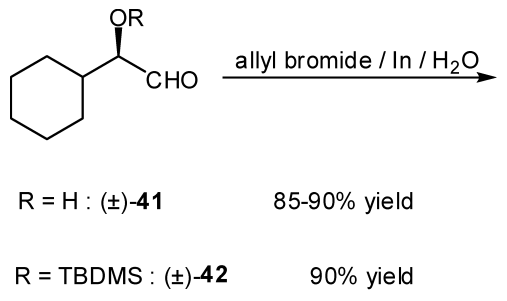<smiles>C=CCC(O)C(O)C1CCCCC1</smiles><smiles>C=CC[C@@H](O)C(O)C1CCCCC1</smiles>

$$
\mathrm{R}=\mathrm{H}: \operatorname{syn}-( \pm)-\mathbf{4 3}
$$$$
\text { (syn: anti }=9.8: 1 \text { ) }
$$

$\mathrm{R}=\mathrm{TBDMS}:$ syn $-( \pm)-45$ (syn : anti $=1: 3.9)$

Chart 8

less polar ( \pm )-35 was determined to be 4,5-syn- and 5,6-syn. In the nucleophilic addition to 2,3-syn-disubstituted butanal derivative $( \pm)-14$, no stereoselective reaction occurred and the reason for this is discussed later in the text.

Formal Synthesis of $( \pm)$-Olivose (4) The reaction of $( \pm)-16$ with allyl bromide in the presence of In gave an inseparable 8:1 diastereomeric mixture of $( \pm)$-38 and ( \pm )-39 ( $93 \%$ yield) as shown in Chart 7. Protection of the secondary alcohol group of this mixture as a tetrahydropyranyl group followed by consecutive desilylation, $\mathrm{K}_{2} \mathrm{CO}_{3}$ treatment and acidification with $\mathrm{AcOH}$ gave epoxy alcohol $( \pm)-\mathbf{4 0}$ in $17 \%$ yield (four steps). Spectral data $\left({ }^{1} \mathrm{H}-\right.$ and $\left.{ }^{13} \mathrm{C}-\mathrm{NMR}\right)$ of the synthetic ( \pm )-40 were identical with those of the reported
$( \pm)-40 .{ }^{17)}$ The synthesis of ( \pm )-4 from ( \pm )-40 was already achieved. ${ }^{17)}$ Consequently, the stereochemistry of the major component ( \pm -38 was determined to be 4,5-anti- and 5,6anti. The stereoselective formation of $( \pm)-\mathbf{3 8}$ from $( \pm)-\mathbf{1 6}$ is explained later in the text.

\section{Disscussion}

The reaction of $\alpha$-hydroxy aldehyde ( \pm )-41 with allyl bromide in the presence of In in water was reported to give 1,2syn adduct $( \pm)-\mathbf{4 3}$ and 1,2-anti adduct $( \pm)-\mathbf{4 4}$ in a ratio of $9.8: 1$, while that of $\alpha$-protected aldehyde $( \pm)-\mathbf{4 2}$ with allyl bromide in the presence of In in water was reported to afford 1,2-syn adduct ( \pm -45 and 1,2-anti adduct $( \pm)-\mathbf{4 6}$ in a ratio 


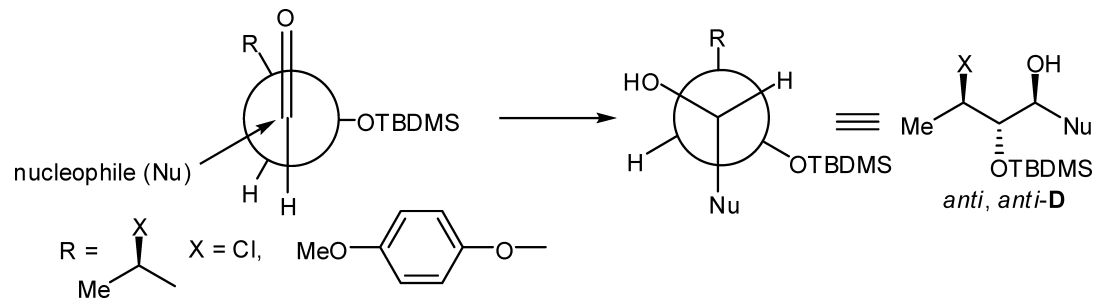

Fig. 1. Felkin-Anh Model for the Preparation of anti, anti-D

of $1: 3.9$ as shown in Chart 8 . The syn-selectivity could be explained by chelation controll and the anti-selectivity could be interpreted as being non-chelation-controlled. ${ }^{18)}$

The $\mathrm{C}(4)-\mathrm{C}(5)$-anti-stereoselective addition against anti-B aldehydes $( \pm)-\mathbf{1 0}$ and $( \pm)-\mathbf{1 6}$ could be explained by Paquette and Mitzel $^{18)}$ who showed that 1,2-addition of the allylindium reagents to $\alpha$-oxygenated aldehydes gave the nonchelation-controlled product, corresponding to the 1,2-anti product by the Felkin-Anh transition state model as shown in Fig. 1. No stereoselection was observed in the reaction of syn-B aldehydes ( \pm )-14 with allyl bromide in the presence of In in water. This fact is not sufficiently explained at the present stage, but is presumed to be due the syn- and anti-structures of the starting 1,2-disubstituted aldehyde.

\section{Conclusion}

The reaction of 2,3-anti-disubstituted butanal derivatives anti-B derived from trans-(2,3)-epoxy butanoate (1) with carbon nucleophile [ $\alpha$-furyl anion, acetate anion, and indium (In)-assisted allyl anion] gave selectively the anti-, antiadduct $\mathbf{D}$. This anti-stereoselection could be explained by the Felkin-Anh transition state model. Thus obtained anti-, antiadducts $( \pm)-\mathbf{1 7}$ and $( \pm)-\mathbf{3 8}$ were formally converted to natural products, $( \pm)$-asperlin (2) and ( \pm )-olivose (4), respectively. The major anti-, anti-adduct $( \pm)-\mathbf{2 6}$ was converted to ( \pm )-digitoxose (3), while the minor anti-, syn-adduct $( \pm)-27$ was also converted to $( \pm)$-olivose (4). Alternately, the reaction of 2,3-syn-disubstituted butanal derivatives syn-B derived from trans-(2,3)-epoxy butanoate (1) with a carbon nucleophile (In-assisted allyl anion) afforded a $c a$. 1:1 mixture of the syn-, anti-adduct $\mathbf{E}[( \pm)-32$ or (士)-34] and the syn-, syn-adduct $\mathbf{F}[( \pm)-33$ or $( \pm)-35]$. After separation of this mixture, $( \pm)-34$ and $( \pm)-35$ were converted to $( \pm)$-oliose (5) and $( \pm)$-boivinose $(6)$, respectively.

\section{Experimental}

${ }^{1} \mathrm{H}$ - and ${ }^{13} \mathrm{C}$-NMR spectra were recorded on JEOL AL 400 spectrometer in $\mathrm{CDCl}_{3}$. High-resolution mass spectra (HR-MS) and the fast atom bombardment mass spectra (FAB-MS) were obtained with a JEOL JMS-600H spectrometer. High-resolution FAB-MS were obtained with a JEOL JMSSX-102A or JMS-T100LP. IR spectra were recorded with a JASCO FT/IR300 spectrometer. All evaporations were performed under reduced pressure. For column chromatography, silica gel (Kieselgel 60) was employed.

( \pm )-2,3-anti-2- ${ }^{t}$ Butyldimethylsiloxy-3-p-methoxyphenoxybutanal (10) i) To a solution of $( \pm)-7(3.13 \mathrm{~g}, 42.9 \mathrm{mmol})$ in $N, N$-dimethylformamide (DMF) $(120 \mathrm{ml})$ were added imidazole $(5.83 \mathrm{~g}, 86 \mathrm{mmol})$ and tert-butyldimethylsilyl chloride (TBDMSCl; $12.9 \mathrm{~g}, 86 \mathrm{mmol}$ ) and the reaction mixture was stirred for $12 \mathrm{~h}$ at $\mathrm{rt}$. The reaction mixture was diluted with brine and extracted with AcOEt. The organic layer was dried over $\mathrm{MgSO}_{4}$ and evaporated to give a crude oil, which was chromatographed on silica gel ( $250 \mathrm{~g}, n$-hexane : $\mathrm{AcOEt}=40: 1)$ to give $( \pm)-3(13.3 \mathrm{~g}, 88 \%)$ as a colorless oil. ( \pm )-8: IR (neat): $1759 \mathrm{~cm}^{-1} ;{ }^{1} \mathrm{H}-\mathrm{NMR} \delta$ : $0.05(3 \mathrm{H}, \mathrm{s}), 0.06(3 \mathrm{H}, \mathrm{s}), 0.92$ $(9 \mathrm{H}, \mathrm{s}), 1.28(3 \mathrm{H}, \mathrm{d}, J=6.2 \mathrm{~Hz}), 3.73(3 \mathrm{H}, \mathrm{s}), 3.76(3 \mathrm{H}, \mathrm{s}), 4.41(1 \mathrm{H}, \mathrm{d}$,
$J=4.4 \mathrm{~Hz}), 4.57(1 \mathrm{H}, \mathrm{dq}, J=4.4,6.2 \mathrm{~Hz}), 6.80-6.87(4 \mathrm{H}, \mathrm{m}) .{ }^{13} \mathrm{C}-\mathrm{NMR} \delta$ : $-5.16,-5.14,14.8,18.3,25.6$ (3C), 52.0, 55.6, 74.3, 75.9, 114.6 (2C), 117.1 (2C), 151.2, 154.1, 172.4. HR-MS (electron impact ionization (EI)): Calcd for $\mathrm{C}_{18} \mathrm{H}_{30} \mathrm{O}_{5} \mathrm{Si}\left(\mathrm{M}^{+}\right)$: 354.1863 , Found: 354.1867 . ii) To a solution of $( \pm)-8(5.08 \mathrm{~g}, 14 \mathrm{mmol})$ in dry toluene $(60 \mathrm{ml})$ were added $1 \mathrm{M}$ solution of diisobutylaluminum hydride (Dibal-H) in toluene $(34 \mathrm{ml}, 34 \mathrm{mmol})$ under ice cooling and the reaction mixture was stirred for $1 \mathrm{~h}$ at the same temperature. The reaction mixture was diluted with $\mathrm{H}_{2} \mathrm{O}$ and filtered off with the aid of celite. The filtrate was extracted with AcOEt. The organic layer was dried over $\mathrm{MgSO}_{4}$ and evaporated to give a crude oil, which was chromatographed on silica gel $(120 \mathrm{~g}, n$-hexane : $\mathrm{AcOEt}=10: 1)$ to give $( \pm)-9(3.6 \mathrm{~g}, 77 \%)$ as a colorless oil. $( \pm)-9$ : IR (neat): $3447 \mathrm{~cm}^{-1} ;{ }^{1} \mathrm{H}-\mathrm{NMR} \delta: 0.12(3 \mathrm{H}, \mathrm{s}), 0.14$ $(3 \mathrm{H}, \mathrm{s}), 0.92(9 \mathrm{H}, \mathrm{s}), 1.26(3 \mathrm{H}, \mathrm{d}, J=6.4 \mathrm{~Hz}), 3.66(1 \mathrm{H}, \mathrm{dd}, J=4.2,11.2 \mathrm{~Hz})$ $3.74(1 \mathrm{H}, \mathrm{dd}, J=4.2,11.2 \mathrm{~Hz}), 3.76(3 \mathrm{H}, \mathrm{s}), 3.82(1 \mathrm{H}, \mathrm{dt}, J=4.2,5.8 \mathrm{~Hz})$, $4.30(1 \mathrm{H}, \mathrm{dq}, J=5.8,6.4 \mathrm{~Hz}), 6.79-6.87(4 \mathrm{H}, \mathrm{m}) .{ }^{13} \mathrm{C}-\mathrm{NMR} \delta:-4.55$, $-4.53,15.8,18.1,25.8(3 \mathrm{C}), 55.6,63.9,75.1,75.4,114.6$ (2C), 117.3 (2C), 151.6, 154.0. HR-MS (EI): Calcd for $\mathrm{C}_{17} \mathrm{H}_{30} \mathrm{O}_{4} \mathrm{Si}\left(\mathrm{M}^{+}\right)$: 326.1913, Found: 326.1943. iii) To a solution of ( \pm )-9 $(1.48 \mathrm{~g}, 4.5 \mathrm{mmol})$ in $\mathrm{CH}_{2} \mathrm{Cl}_{2}(30 \mathrm{ml})$ was added pyridinium chlorochromate (PCC; $1.95 \mathrm{~g}, 9 \mathrm{mmol}$ ) at $\mathrm{rt}$ and the reaction mixture was stirred for $15 \mathrm{~h}$ at the same temperature. The reaction mixture was filtered off with the aid of celite. The filtrate was concentrated to give a residue, which was chromatographed on silica gel $(50 \mathrm{~g}, n$ hexane : $\mathrm{AcOEt}=50: 1)$ to give $( \pm)-\mathbf{1 0}(1.11 \mathrm{~g}, 75 \%)$ as a colorless oil. $( \pm)$ 10; IR (neat): $1736 \mathrm{~cm}^{-1}$; ${ }^{1} \mathrm{H}-\mathrm{NMR} \delta: 0.07(3 \mathrm{H}, \mathrm{s}), 0.11(3 \mathrm{H}, \mathrm{s}), 0.94(9 \mathrm{H}$, s), $1.28(3 \mathrm{H}, \mathrm{d}, J=6.4 \mathrm{~Hz}), 3.76(3 \mathrm{H}, \mathrm{s}), 4.23(1 \mathrm{H}, \mathrm{dd}, J=1.4,3.6 \mathrm{~Hz}), 4.53$ $(1 \mathrm{H}, \mathrm{dq}, J=3.6,6.4 \mathrm{~Hz}), 6.80-6.86(4 \mathrm{H}, \mathrm{m}), 9.69(1 \mathrm{H}, \mathrm{d}, J=1.4 \mathrm{~Hz}) .{ }^{13} \mathrm{C}-$ NMR $\delta:-4.86,-4.76,15.1,18.2,25.7$ (3C), 55.6, 75.5, 79.5, 114.7 (2C), 117.1 (2C), 151.1, 154.2, 203.5. HR-MS (EI): Calcd for $\mathrm{C}_{17} \mathrm{H}_{28} \mathrm{O}_{4} \mathrm{Si}\left(\mathrm{M}^{+}\right)$: 324.1757, Found: 324.1783.

( \pm )-2,3-syn-2- ${ }^{t}$ Butyldimethylsiloxy-3-p-methoxyphenoxybutanal (14) i) To a solution of $( \pm)-7(6.0 \mathrm{~g}, 25 \mathrm{mmol})$ in tetrahydrofuran (THF) $(80 \mathrm{ml})$ were added benzoic acid $(5.49 \mathrm{~g}, 45 \mathrm{mmol})$ and triphenylphosphine $(11.76 \mathrm{~g}$, $45 \mathrm{mmol})$, and diisopropylazodicarboxylate $(40 \%$ in toluene, $9.45 \mathrm{~g}$, $36 \mathrm{mmol}$ ) was added dropwise under argon atmosphere at $-78^{\circ} \mathrm{C}$. The reaction mixture was stirred for $1 \mathrm{~h}$ at the same temperature. The reaction mixture was condensed and the residue was diluted with $\mathrm{H}_{2} \mathrm{O}$, extracted with AcOEt. The organic layer was dried over $\mathrm{MgSO}_{4}$ and evaporated to give a crude residue, which was filtered off with the aid of celite to afford filtrate. The filtrate was evaporated to give a crude product. To a solution of above crude mixture in $\mathrm{MeOH}(130 \mathrm{ml})$ was added $\mathrm{K}_{2} \mathrm{CO}_{3}(6.9 \mathrm{~g}, 48 \mathrm{mmol})$ and the reaction mixture was stirred for $1 \mathrm{~h}$ at the same temperature. The reaction mixture was condensed and the residue was diluted with $\mathrm{H}_{2} \mathrm{O}$, extracted with AcOEt. The organic layer was washed with $1 \mathrm{M}$ aqueous $\mathrm{NaOH}(100 \mathrm{ml})$ and brine. The organic layer was dried over $\mathrm{MgSO}_{4}$ and evaporated to give a crude residue, which was chromatographed on silica gel $(120 \mathrm{~g}, n$ hexane : $\mathrm{AcOEt}=5: 1)$ to give $( \pm)-\mathbf{1 1}(3.48 \mathrm{~g}, 58 \%)$ as a colorless oil. $( \pm)-$ 11: IR (neat): $3479,1737 \mathrm{~cm}^{-1}$; ${ }^{1} \mathrm{H}-\mathrm{NMR} \delta: 1.39(3 \mathrm{H}, \mathrm{d}, J=6.4 \mathrm{~Hz}), 3.07$ $(1 \mathrm{H}, \mathrm{d}, J=8.0 \mathrm{~Hz}), 3.73(3 \mathrm{H}, \mathrm{s}), 3.76(3 \mathrm{H}, \mathrm{s}), 4.20(1 \mathrm{H}, \mathrm{dd}, J=2.4,8.0 \mathrm{~Hz})$, $4.60(1 \mathrm{H}, \mathrm{dq}, J=2.4,6.4 \mathrm{~Hz}), 6.79-6.85(4 \mathrm{H}, \mathrm{m}) .{ }^{13} \mathrm{C}-\mathrm{NMR} \delta: 15.7,52.5$, 55.6, 73.8, 76.4, 114.5 (2C), 118.2 (2C), 151.3, 154.6, 173.0. HR-MS (EI): Calcd for $\mathrm{C}_{12} \mathrm{H}_{16} \mathrm{O}_{5}\left(\mathrm{M}^{+}\right)$: 240.0998, Found: 240.0996. ii) To a solution of $( \pm)-11(2.68 \mathrm{~g}, 11 \mathrm{mmol})$ in DMF $(30 \mathrm{ml})$ were added imidazole $(1.52 \mathrm{~g}$, $22 \mathrm{mmol}$ ) and tert-butyldimethylsilyl chloride (TBDMSCl; $3.36 \mathrm{~g}, 22 \mathrm{mmol}$ ) and the reaction mixture was stirred for $12 \mathrm{~h}$ at $\mathrm{rt}$. The reaction mixture was worked up in the same way as $( \pm)-\mathbf{8}$ to give $( \pm)-12(3.63 \mathrm{~g}, 92 \%)$ as a colorless oil. ( \pm )-12: IR (neat): $1754 \mathrm{~cm}^{-1} ;{ }^{1} \mathrm{H}-\mathrm{NMR} \delta: 0.05(3 \mathrm{H}, \mathrm{s}), 0.12(3 \mathrm{H}$, s), $0.91(9 \mathrm{H}, \mathrm{s}), 1.27(3 \mathrm{H}, \mathrm{d}, J=6.2 \mathrm{~Hz}), 3.72(3 \mathrm{H}, \mathrm{s}), 3.76(3 \mathrm{H}, \mathrm{s}), 4.30(1 \mathrm{H}$ d, $J=6.0 \mathrm{~Hz}), 4.75(1 \mathrm{H}, \mathrm{dq}, J=6.0,6.2 \mathrm{~Hz}), 6.78-6.90(4 \mathrm{H}, \mathrm{m}) .{ }^{13} \mathrm{C}-\mathrm{NMR}$ $\delta:-5.2,-5.0,15.7,18.4,25.7(3 \mathrm{C}), 51.8,55.6,75.6,77.4,114.5(2 \mathrm{C})$, 118.3 (2C), 152.0, 154.4, 172.0. HR-MS (EI): Calcd for $\mathrm{C}_{18} \mathrm{H}_{30} \mathrm{O}_{5} \mathrm{Si}\left(\mathrm{M}^{+}\right)$: 354.1863, Found: 354.1864 . iii) To a solution of $( \pm)-7(3.44 \mathrm{~g}, 10 \mathrm{mmol})$ in 
dry toluene $(50 \mathrm{ml})$ were added $1 \mathrm{~m}$ solution of diisobutylaluminum hydride (Dibal-H) in toluene $(22 \mathrm{ml}, 22 \mathrm{mmol})$ under ice cooling and the reaction mixture was stirred for $1 \mathrm{~h}$ at the same temperature. The reaction mixture was worked up in the same way as $( \pm)-\mathbf{9}$ to give $( \pm)-\mathbf{1 3}(2.78 \mathrm{~g}, 88 \%)$ as a colorless oil. $( \pm)-13$ : IR (neat): $3458 \mathrm{~cm}^{-1} ;{ }^{1} \mathrm{H}-\mathrm{NMR} \delta$ : $0.06(3 \mathrm{H}, \mathrm{s}), 0.12$ $(3 \mathrm{H}, \mathrm{s}), 0.90(9 \mathrm{H}, \mathrm{s}), 1.23(3 \mathrm{H}, \mathrm{d}, J=6.4 \mathrm{~Hz}), 2.06(1 \mathrm{H}, \mathrm{dd}, J=5.3,7.2 \mathrm{~Hz})$, $3.66-3.69(1 \mathrm{H}, \mathrm{m}), 3.74-3.80(1 \mathrm{H}, \mathrm{m}), 3.76(3 \mathrm{H}, \mathrm{s}), 3.86-3.90(1 \mathrm{H}, \mathrm{m})$, $4.32(1 \mathrm{H}$, quintet, $J=6.4 \mathrm{~Hz}), 6.80-6.85(4 \mathrm{H}, \mathrm{m}) .{ }^{13} \mathrm{C}-\mathrm{NMR} \delta:-4.81$, $-4.47,14.8,18.1,25.8$ (3C), 55.7, 63.4, 74.5, 76.4, 114.6 (2C), 117.3 (2C), 151.6, 154.0. HR-MS (EI): Calcd for $\mathrm{C}_{17} \mathrm{H}_{30} \mathrm{O}_{4} \mathrm{Si}\left(\mathrm{M}^{+}\right)$: 326.1913, Found 326.1917. iv) To a solution of ( \pm -13 $(2.55 \mathrm{~g}, 8 \mathrm{mmol})$ in $\mathrm{CH}_{2} \mathrm{Cl}_{2}(30 \mathrm{ml})$ was added pyridinium chlorochromate (PCC; $3.37 \mathrm{~g}, 17 \mathrm{mmol})$ at $\mathrm{rt}$ and the reaction mixture was stirred for $12 \mathrm{~h}$ at the same temperature. The reaction mixture was worked up in the same way as $( \pm)-\mathbf{1 0}$ to give $( \pm)-\mathbf{1 4}(2.00 \mathrm{~g}$ $79 \%$ ) as a colorless oil. ( \pm )-14; IR (neat): $1737 \mathrm{~cm}^{-1},{ }^{1} \mathrm{H}-\mathrm{NMR} \delta: 0.08(3 \mathrm{H}$, s), $0.11(3 \mathrm{H}, \mathrm{s}), 0.94(9 \mathrm{H}, \mathrm{s}), 1.31(3 \mathrm{H}, \mathrm{d}, J=6.4 \mathrm{~Hz}), 3.76(3 \mathrm{H}, \mathrm{s}), 4.13(1 \mathrm{H}$, dd, $J=0.8,4.8 \mathrm{~Hz}), 4.48(1 \mathrm{H}, \mathrm{dq}, J=4.8,6.4 \mathrm{~Hz}), 6.80-6.89(4 \mathrm{H}, \mathrm{m}), 9.75$ $(1 \mathrm{H}, \mathrm{d}, J=0.8 \mathrm{~Hz}) .{ }^{13} \mathrm{C}-\mathrm{NMR} \delta:-5.02,-4.68,15.5,18.3,25.7$ (3C), 55.6, 76.7, 79.6, 114.6 (2C), 118.1 (2C), 151.3, 154.5, 202.9. HR-MS (EI): Calcd for $\mathrm{C}_{17} \mathrm{H}_{28} \mathrm{O}_{4} \mathrm{Si}\left(\mathrm{M}^{+}\right): 324.1757$, Found: 324.1761 .

(士)-(1,2-anti, 2,3-anti)-2- ${ }^{t}$ Butyldimethylsiloxy-1-(2-furyl)-3-p-methoxyphenoxybutanol (17) and ( \pm )-(1,2-syn, 2,3-anti)-2- ${ }^{-}$Butyldimethylsiloxy-1-(2-furyl)-3-p-methoxyphenoxybutanol (18) To a solution of furan $(1.73 \mathrm{~g}, 25 \mathrm{mmol})$ in THF $(30 \mathrm{ml})$ was added $1.5 \mathrm{~m}$ solution of $n$-butyllithium in pentane $(17 \mathrm{ml}, 25 \mathrm{mmol})$ under argon atmosphere at $-78^{\circ} \mathrm{C}$ and the reaction mixture was stirred for $1.5 \mathrm{~h}$ at the same temperature. A solution of $( \pm)-10(3.32 \mathrm{~g}, 10 \mathrm{mmol})$ in THF $(5 \mathrm{ml})$ was added to the above mixture and the whole was stirred for $40 \mathrm{~min}$ at $\mathrm{rt}$. The reaction mixture was diluted with saturated $\mathrm{NH}_{4} \mathrm{Cl}$ solution and extracted with AcOEt. The organic layer was washed with brine and dried over $\mathrm{MgSO}_{4}$. Evaporation of the organic solvent gave a residue, which was chromatographed on silica gel (50 g, $n$ hexane : $\mathrm{AcOEt}=20: 1)$ to give $( \pm)-18(0.35 \mathrm{~g}, 17 \%)$ and $( \pm)-17(1.61 \mathrm{~g}$, $77 \%$ ) as a colorless oil in elution order. $( \pm)-17$ : IR (neat): $3451 \mathrm{~cm}^{-1} ;{ }^{1} \mathrm{H}$ NMR $\delta:-0.15(3 \mathrm{H}, \mathrm{s}), 0.11(3 \mathrm{H}, \mathrm{s}), 0.83(9 \mathrm{H}, \mathrm{s}), 1.28(3 \mathrm{H}, \mathrm{d}, J=6.4 \mathrm{~Hz})$ $2.22(1 \mathrm{H}, \mathrm{d}, J=4.9 \mathrm{~Hz}), 3.76(3 \mathrm{H}, \mathrm{s}), 4.27(1 \mathrm{H}, \mathrm{dd}, J=2.9,6.8 \mathrm{~Hz}), 4.53(1 \mathrm{H}$ $\mathrm{dq}, J=2.9,6.4 \mathrm{~Hz}), 4.68(1 \mathrm{H}, \mathrm{dd}, J=4.9,6.8 \mathrm{~Hz}), 6.31(1 \mathrm{H}, \mathrm{d}, J=3.2 \mathrm{~Hz})$, $6.34(1 \mathrm{H}, \mathrm{dd}, J=1.9,3.2 \mathrm{~Hz}), 6.78(2 \mathrm{H}, \mathrm{d}, J=9.3 \mathrm{~Hz}), 6.81(2 \mathrm{H}, \mathrm{d}$, $J=9.3 \mathrm{~Hz}), 7.37(1 \mathrm{H}, \mathrm{d}, J=1.9 \mathrm{~Hz}) .{ }^{13} \mathrm{C}-\mathrm{NMR} \delta:-5.34,-4.28,14.0,18.2$, $25.8(3 \mathrm{C}), 55.7,69.8,74.5,75.6,108.2,110.5,114.7(2 \mathrm{C}), 116.6(2 \mathrm{C})$, 141.9, 151.6, 153.7, 154.0. HR-MS (EI): Calcd for $\mathrm{C}_{21} \mathrm{H}_{32} \mathrm{O}_{5} \mathrm{Si}\left(\mathrm{M}^{+}\right)$: 392.2019, Found: 392.2017. (土)-18: IR (neat): $3520 \mathrm{~cm}^{-1} ;{ }^{1} \mathrm{H}-\mathrm{NMR} \delta$ : $-0.12(3 \mathrm{H}, \mathrm{s}), 0.13(3 \mathrm{H}, \mathrm{s}), 0.91(9 \mathrm{H}, \mathrm{s}), 1.27(3 \mathrm{H}, \mathrm{d}, J=5.4 \mathrm{~Hz}), 2.99(1 \mathrm{H}$, d, $J=5.8 \mathrm{~Hz}), 3.76(3 \mathrm{H}, \mathrm{s}), 4.20-4.24(2 \mathrm{H}, \mathrm{m}), 4.74(1 \mathrm{H}, \mathrm{dd}, J=5.8$, $6.8 \mathrm{~Hz}), 6.33(1 \mathrm{H}, \mathrm{d}, J=3.2 \mathrm{~Hz}), 6.36(1 \mathrm{H}, \mathrm{dd}, J=1.5,3.2 \mathrm{~Hz}), 6.74(2 \mathrm{H}, \mathrm{d}$, $J=9.3 \mathrm{~Hz}), 6.79(2 \mathrm{H}, \mathrm{d}, J=9.3 \mathrm{~Hz}), 7.40(1 \mathrm{H}, \mathrm{d}, J=1.5 \mathrm{~Hz}) .{ }^{13} \mathrm{C}-\mathrm{NMR} \delta$ : $-5.31,-4.10,14.9,18.3,26.0$ (3C), 55.7, 68.8, 75.2, 76.3, 107.6, 110.5, 114.7 (2C), 117.0 (2C), 141.9, 151.3, 154.0, 154.2. HR-MS (EI): Calcd for $\mathrm{C}_{21} \mathrm{H}_{32} \mathrm{O}_{5} \mathrm{Si}\left(\mathrm{M}^{+}\right): 392.2019$, Found: 392.2020 .

(士)-(1,2-anti, 2,3-trans)-1-(2-Furyl)-2,3-epoxybutanol (22) i) To a solution of $( \pm)-17(0.865 \mathrm{~g}, 2.2 \mathrm{mmol})$ in pyridine $(15 \mathrm{ml})$ were added benzoyl chloride (0.46 g, $3.3 \mathrm{mmol}$ ) and 4-dimethylaminopyridine (DMAP; $35 \mathrm{mg} \mathrm{g}$, $0.3 \mathrm{mmol}$ ) and the reaction mixture was stirred for $3 \mathrm{~h}$ at $\mathrm{rt}$. The reaction mixture was diluted with $\mathrm{H}_{2} \mathrm{O}$ and extracted with AcOEt. The organic layer was washed with $2 \mathrm{M} \mathrm{HCl}$ and brine. The organic layer was dried over $\mathrm{MgSO}_{4}$ and evaporated to give a crude oil, which was chromatographed on silica gel $(50 \mathrm{~g}, n$-hexane : $\mathrm{AcOEt}=35: 1)$ to give $( \pm)-19(1.09 \mathrm{~g}, 84 \%)$ as a colorless oil. ( \pm )-19: IR (neat): $1721 \mathrm{~cm}^{-1}$; ${ }^{1} \mathrm{H}-\mathrm{NMR} \delta:-0.16(3 \mathrm{H}, \mathrm{s}), 0.12$ $(3 \mathrm{H}, \mathrm{s}), 0.81(9 \mathrm{H}, \mathrm{s}), 1.30(3 \mathrm{H}, \mathrm{d}, J=6.2 \mathrm{~Hz}), 3.77(3 \mathrm{H}, \mathrm{s}), 4.51(1 \mathrm{H}, \mathrm{dq}$, $J=2.8,6.2 \mathrm{~Hz}), 4.66(1 \mathrm{H}, \mathrm{dd}, J=2.8,7.6 \mathrm{~Hz}), 6.07(1 \mathrm{H}, \mathrm{d}, J=7.6 \mathrm{~Hz}), 6.34$ $(1 \mathrm{H}, \mathrm{dd}, J=1.6,3.4 \mathrm{~Hz}), 6.47(1 \mathrm{H}, \mathrm{dd}, J=0.8,3.4 \mathrm{~Hz}), 6.81(4 \mathrm{H}, \mathrm{br}) .7 .38$ $(1 \mathrm{H}, \mathrm{dd}, J=0.8,1.6 \mathrm{~Hz}), 7.42-7.46(2 \mathrm{H}, \mathrm{m}), 7.55-7.59(1 \mathrm{H}, \mathrm{m}), 8.04$ $8.07(2 \mathrm{H}, \mathrm{m}) .{ }^{13} \mathrm{C}-\mathrm{NMR} \delta:-5.48,-4.27,13.5,18.2,25.8(3 \mathrm{C}), 55.7,70.0$, 73.9, 74.4, 110.5, 110.9, 114.7 (2C), 116.6 (2C), 127.78 (2C), 129.83 (2C), 133.2 (2C), 133.2, 142.3, 150.5, 151.6, 153.8, 165.1. HR-MS (EI): Calcd for $\mathrm{C}_{28} \mathrm{H}_{36} \mathrm{O}_{6} \mathrm{Si}\left(\mathrm{M}^{+}\right)$: 496.2281, Found: 496.2216. ii) To a solution of $( \pm)-19$ $(116 \mathrm{mg}, 0.23 \mathrm{mmol})$ in $\mathrm{MeCN}(4 \mathrm{ml})$ was added a solution of ceric ammonium nitrate (CAN; $236 \mathrm{mg}, 0.43 \mathrm{mmol})$ in $\mathrm{H}_{2} \mathrm{O}(1 \mathrm{ml})$ at $\mathrm{rt}$ and the reaction mixture was stirred for $0.5 \mathrm{~h}$ at the same temperature. The reaction mixture was diluted with $\mathrm{H}_{2} \mathrm{O}$ and extracted with AcOEt. The organic layer was washed with brine and dried over $\mathrm{MgSO}_{4}$. Evaporation of the organic solvent gave a residue, which was chromatographed on silica gel $(10 \mathrm{~g}, n$ hexane : $\mathrm{AcOEt}=20: 1)$ to give $( \pm)-\mathbf{2 0}(52 \mathrm{mg}, 57 \%)$ as a colorless oil. ( \pm )20: IR (neat): $3725,1726 \mathrm{~cm}^{-1} ;{ }^{1} \mathrm{H}-\mathrm{NMR} \delta$ : $-0.16(3 \mathrm{H}, \mathrm{s}), 0.09(3 \mathrm{H}, \mathrm{s})$, $0.84(9 \mathrm{H}, \mathrm{s}), 1.24(3 \mathrm{H}, \mathrm{d}, J=6.4 \mathrm{~Hz}), 1.81(1 \mathrm{H}, \mathrm{br} \mathrm{s}), 3.92(1 \mathrm{H}, \mathrm{dq}, J=3.5$,
$6.4 \mathrm{~Hz}), 4.38(1 \mathrm{H}, \mathrm{q}, J=3.5,7.0 \mathrm{~Hz}), 6.10(1 \mathrm{H}, \mathrm{d}, J=7.0 \mathrm{~Hz}), 6.34(1 \mathrm{H}, \mathrm{dd}$, $J=2.0,3.2 \mathrm{~Hz}), 6.49(1 \mathrm{H}, \mathrm{d}, J=3.2 \mathrm{~Hz}), 7.39(1 \mathrm{H}, \mathrm{dd}, J=0.8,2.0 \mathrm{~Hz})$, $7.41-7.45(2 \mathrm{H}, \mathrm{m}), 7.53-7.58(1 \mathrm{H}, \mathrm{m}), 8.02-8.05(2 \mathrm{H}, \mathrm{m}) .{ }^{13} \mathrm{C}-\mathrm{NMR} \delta$ : $-5.29,-4.54,17.5,18.1,25.8$ (3C), 68.8, 69.8, 75.8, 110.5, 110.6, 128.4 (2C), 129.8 (3C), 133.2, 142.3, 150.6, 165.2. HR-MS (CI+): Calcd for $\mathrm{C}_{21} \mathrm{H}_{30} \mathrm{O}_{5} \mathrm{Si}\left(\mathrm{M}^{+}\right): 390.1863$, Found: 390.1872 . iii) To a mixture of $( \pm)-20$ $(145 \mathrm{mg}, 0.37 \mathrm{mmol})$ and $\mathrm{Et}_{3} \mathrm{~N}(0.74 \mathrm{ml})$ and DMAP $(408 \mathrm{mg}, 3.33 \mathrm{ml})$ in $\mathrm{CH}_{2} \mathrm{Cl}_{2}(20 \mathrm{ml})$ was added tosyl chloride $(566 \mathrm{mg}, 2.96 \mathrm{mmol})$ at $\mathrm{rt}$ and the reaction mixture was stirred for $14 \mathrm{~h}$ at the same temperature. The reaction mixture was diluted with $\mathrm{H}_{2} \mathrm{O}$ and extracted with $\mathrm{CH}_{2} \mathrm{Cl}_{2}$. The organic layer was washed with brine and dried over $\mathrm{MgSO}_{4}$. Evaporation of the organic solvent gave a residue, which was chromatographed on silica gel (15 g, nhexane: $\mathrm{AcOEt}=20: 1)$ to give $( \pm)-\mathbf{2 1}(174 \mathrm{mg}, 86 \%)$ as a colorless oil. (土)-21: IR (neat): $1725 \mathrm{~cm}^{-1} ;{ }^{1} \mathrm{H}-\mathrm{NMR} \delta:-0.23(3 \mathrm{H}, \mathrm{s}), 0.10(3 \mathrm{H}, \mathrm{s}), 0.75$ $(9 \mathrm{H}, \mathrm{s}), 1.23(3 \mathrm{H}, \mathrm{d}, J=6.4 \mathrm{~Hz}), 2.42(3 \mathrm{H}, \mathrm{s}), 4.65(1 \mathrm{H}, \mathrm{dd}, J=2.0,8.8 \mathrm{~Hz})$, $4.38(1 \mathrm{H}, \mathrm{dq}, J=2.0,6.4 \mathrm{~Hz}), 5.79(1 \mathrm{H}, \mathrm{d}, J=8.8 \mathrm{~Hz}), 6.32(1 \mathrm{H}, \mathrm{dd}, J=1.6$, $3.2 \mathrm{~Hz}), 6.49(1 \mathrm{H}, \mathrm{dd}, J=0.8,3.2 \mathrm{~Hz}), 7.26(2 \mathrm{H}, \mathrm{d}, J=8.4 \mathrm{~Hz}), 7.37(1 \mathrm{H}$, dd, $J=0.8,1.6 \mathrm{~Hz}), 7.44-7.48(2 \mathrm{H}, \mathrm{m}), 7.58-7.62(1 \mathrm{H}, \mathrm{m}), 7.74(2 \mathrm{H}, \mathrm{d}$, $J=8.4 \mathrm{~Hz}), 7.99-8.02(2 \mathrm{H}, \mathrm{m}) .{ }^{13} \mathrm{C}-\mathrm{NMR} \delta:-5.82,-4.51,13.5,18.1$, $21.6,25.6$ (3C), 69.1, 73.8, 79.3, 110.6, 111.4, 127.8 (2C), 128.5 (2C), 129.4, 129.7 (2C), 129.8 (2C), 130.2, 133.4, 142.6, 144.6, 149.6, 164.8. HRMS (FAB): Calcd for $\mathrm{C}_{28} \mathrm{H}_{37} \mathrm{O}_{7} \mathrm{SSi}\left(\mathrm{M}^{+}+1\right)$ : 545.2029, Found: 545.2072 . iv) To a solution of $( \pm)-\mathbf{2 1}(205 \mathrm{mg}, 0.38 \mathrm{mmol})$ in THF $(6 \mathrm{ml})$ was added a $1.0 \mathrm{M}$ solution of tetrabutylammonium fluoride (TBAF) in THF $(3 \mathrm{ml})$ and the reaction mixture was stirred for $3 \mathrm{~h}$ at $\mathrm{rt}$. To the above mixture was added $\mathrm{K}_{2} \mathrm{CO}_{3}(105 \mathrm{mg}, 0.75 \mathrm{mmol})$ and the reaction mixture was stirred for $6 \mathrm{~h}$ at rt. The reaction mixture was diluted with $\mathrm{H}_{2} \mathrm{O}$ and extracted with $\mathrm{CHCl}_{3}$. The organic layer was washed with brine and dried over $\mathrm{MgSO}_{4}$. Evaporation of the organic solvent gave a residue, which was chromatographed on silica gel $(10 \mathrm{~g}, n$-hexane : AcOEt $=4: 1)$ to give $( \pm)-22(36 \mathrm{mg}, 61 \%)$ as a colorless oil. (士)-22: IR (neat): $3401 \mathrm{~cm}^{-1}$; ${ }^{1} \mathrm{H}-\mathrm{NMR} \delta: 1.38(3 \mathrm{H}, \mathrm{d}$, $J=5.2 \mathrm{~Hz}), 2.34(1 \mathrm{H}$, br s $), 3.05(1 \mathrm{H}, \mathrm{dd}, J=2.4,3.6 \mathrm{~Hz}), 3.25(1 \mathrm{H}, \mathrm{dq}$, $J=2.4,5.2 \mathrm{~Hz}), 4.87(1 \mathrm{H}, \mathrm{d}, J=3.6 \mathrm{~Hz}), 6.35-6.38(2 \mathrm{H}, \mathrm{m}), 7.42(1 \mathrm{H}, \mathrm{dd}$, $J=0.8,1.8 \mathrm{~Hz}) .{ }^{13} \mathrm{C}-\mathrm{NMR} \delta: 17.1,51.7,59.8,65.2,107.7,110.2,142.5$, 152.4. HR-MS (FAB): Calcd for $\mathrm{C}_{8} \mathrm{H}_{11} \mathrm{O}_{3}\left(\mathrm{M}^{+}+1\right)$ : 155.0708, Found: 155.0706

(士)-1,5-Dideoxyhexitol (25) i) $n$-Butyllithium (1.6 $\mathrm{M}$ in hexane, $3.8 \mathrm{ml}$, $6 \mathrm{mmol}$ ) was added to a stirred solution of diisopropylamine $(605 \mathrm{mg}$, $6 \mathrm{mmol})$ in $\mathrm{THF}(30 \mathrm{ml})$ at $-78^{\circ} \mathrm{C}$ under an argon atmosphere and the reaction mixture was stirred for $30 \mathrm{~min}$ at the same temperature. tert-Butyl acetate $(600 \mathrm{mg}, 5.1 \mathrm{mmol})$ was added to the resulting lithium diisopropylamide (LDA)-THF and the reaction mixture was stirred for $0.5 \mathrm{~h}$ at the same temperature. To the above reaction mixture was added a solution of $( \pm)-10(1.4 \mathrm{~g}, 4.3 \mathrm{mmol})$ in THF $(10 \mathrm{ml})$ and the reaction mixture was stirred for $1 \mathrm{~h}$ at the same temperature. The reaction mixture was diluted with $\mathrm{H}_{2} \mathrm{O}$ and extracted with AcOEt. The organic layer was washed with brine and dried over $\mathrm{MgSO}_{4}$. Evaporation of the organic solvent gave a residue, which was chromatographed on silica gel $(55 \mathrm{~g}, n$-hexane: $\mathrm{AcOEt}=40: 1)$ to give $( \pm)-23(1.58 \mathrm{~g}, 83 \%)$ as a colorless oil. ( \pm$)-23$ : IR (neat): $3504,1724 \mathrm{~cm}^{-1} ;{ }^{1} \mathrm{H}-\mathrm{NMR} \delta: 0.06(3 \mathrm{H}, \mathrm{s}), 0.16(3 \mathrm{H}, \mathrm{s}), 0.92(9 \mathrm{H}, \mathrm{s})$, $1.25(3 \mathrm{H}, \mathrm{d}, J=6.4 \mathrm{~Hz}), 1.46(9 \mathrm{H}, \mathrm{s}), 2.04(1 \mathrm{H}, \mathrm{s}), 2.43(1 \mathrm{H}, \mathrm{dd}, J=8.0$, $16.8 \mathrm{~Hz}), 2.65(1 \mathrm{H}, \mathrm{dd}, J=2.8,16.8 \mathrm{~Hz}), 3.39(1 \mathrm{H}, \mathrm{d}, J=4.4 \mathrm{~Hz}), 3.72(3 \mathrm{H}$, s), $3.84-3.92(1 \mathrm{H}, \mathrm{m}), 4.62(1 \mathrm{H}, \mathrm{dq}, J=2.6,6.4 \mathrm{~Hz}), 6.80-6.86(4 \mathrm{H}, \mathrm{m})$. ${ }^{13} \mathrm{C}-\mathrm{NMR} \delta:-4.7,-3.9,13.6,18.3,26.1$ (3C), 28.1 (3C), 38.3, 55.7, 69.4, 74.0, 76.2, 81.5, 114.6 (2C), 116.5 (2C), 151.6, 153.6, 172.8. HR-MS (EI): Calcd for $\mathrm{C}_{23} \mathrm{H}_{40} \mathrm{O}_{6} \mathrm{Si}\left(\mathrm{M}^{+}\right)$: 440.2588, Found: 440.2594. ii) $\mathrm{LiAlH}_{4}$ $(120 \mathrm{mg}, 3.1 \mathrm{mmol})$ was added to a stirred solution of $( \pm)-23(277 \mathrm{mg}$, $0.63 \mathrm{mmol})$ in THF $(5 \mathrm{ml})$ at $-78^{\circ} \mathrm{C}$ and the reaction mixture was stirred for $1 \mathrm{~h}$ at the same temperature. The reaction mixture was diluted with $\mathrm{H}_{2} \mathrm{O}$ and filtered off with the aid of celite. The filtrate was extracted with AcOEt. The organic layer was dried over $\mathrm{MgSO}_{4}$ and evaporated to give a crude oil. To a solution of the above crude mixture in THF $(10 \mathrm{ml})$ was added a $1.0 \mathrm{~m}$ solution of TBAF in THF $(1 \mathrm{ml})$ and the reaction mixture was stirred for $2 \mathrm{~h}$ at $\mathrm{rt}$. Condensation of the reaction mixture gave a crude product. To a solution of the above mixture in pyridine $(3 \mathrm{ml})$ were added a catalytic amount of DMAP and $\mathrm{Ac}_{2} \mathrm{O}(470 \mathrm{mg}, 4.6 \mathrm{mmol})$ and the reaction mixture was stirred for $15 \mathrm{~h}$ at rt. The reaction mixture was diluted with $\mathrm{H}_{2} \mathrm{O}$ and extracted with AcOEt. The organic layer was washed with $1 \mathrm{~m} \mathrm{HCl}$ solution and brine. The organic layer was dried over $\mathrm{MgSO}_{4}$ and evaporated to afford a residue, which was chromatographed on silica gel $(20 \mathrm{~g}, n$-hexane: $\mathrm{AcOEt}=4: 1)$ to give $( \pm)-\mathbf{2 4}(187 \mathrm{mg}, 78 \%)$ as a colorless oil. $( \pm)-24:$ IR (neat): $1736 \mathrm{~cm}^{-1} ;{ }^{1} \mathrm{H}-\mathrm{NMR} \delta: 1.29(3 \mathrm{H}, \mathrm{d}, J=6.4 \mathrm{~Hz}), 1.94-2.12(2 \mathrm{H}, \mathrm{m})$, $1.99(3 \mathrm{H}, \mathrm{s}), 2.05(3 \mathrm{H}, \mathrm{s}), 2.10(3 \mathrm{H}, \mathrm{s}), 3.76(3 \mathrm{H}, \mathrm{s}), 4.00-4.07(1 \mathrm{H}, \mathrm{m})$, $4.11-4.17(1 \mathrm{H}, \mathrm{m}), 4.35(1 \mathrm{H}, \mathrm{dq}, J=6.0,6.4 \mathrm{~Hz}), 5.22(1 \mathrm{H}, \mathrm{dd}, J=3.4$, 
$6.4 \mathrm{~Hz}), 5.37(1 \mathrm{H}, \mathrm{dt}, J=3.4,10.0 \mathrm{~Hz}), 6.81-6.86(4 \mathrm{H}, \mathrm{m}){ }^{13} \mathrm{C}-\mathrm{NMR}$ $\delta: 16.2,20.7,20.8,20.9,28.5,55.6,60.5,69.2,73.6,75.0,114.7$ (2C), 117.5 (2C), 151.0, 154.4, 169.9, 170.1, 170.9. HR-MS (EI): Calcd for $\mathrm{C}_{19} \mathrm{H}_{26} \mathrm{O}_{8}$ $\left(\mathrm{M}^{+}\right)$: 382.1624, Found: 382.1628 . iii) To a solution of $( \pm)-24(187 \mathrm{mg}$, $0.49 \mathrm{mmol})$ in $\mathrm{MeCN}(5 \mathrm{ml})$ and $\mathrm{H}_{2} \mathrm{O}(1 \mathrm{ml})$ was added CAN $(548 \mathrm{mg}$, $1 \mathrm{mmol})$ at $\mathrm{rt}$ and the reaction mixture was stirred for $2 \mathrm{~h}$ at the same temperature. The reaction mixture was diluted with $\mathrm{H}_{2} \mathrm{O}$ and extracted with AcOEt. The organic layer was washed with brine and dried over $\mathrm{MgSO}_{4}$ Evaporation of the organic solvent gave a residue. To the above residue in $\mathrm{MeOH}(15 \mathrm{ml})$ was added $\mathrm{K}_{2} \mathrm{CO}_{3}(273 \mathrm{mg}, 2 \mathrm{mmol})$ and the reaction mixture was stirred for $1 \mathrm{~h}$ at $\mathrm{rt}$. The reaction mixture was filtered off and the filtrate was evaporated to afford a precipitate which was chromatographed on silica gel $(10 \mathrm{~g}, n$-hexane $: \mathrm{AcOEt}=1: 1)$ to give $( \pm)-25$ $(70 \mathrm{mg}, 95 \%)$ as a colorless precipitate. $( \pm)-25$ : IR (neat): $3332 \mathrm{~cm}^{-1} ;{ }^{1} \mathrm{H}-$ NMR $\left(\mathrm{D}_{2} \mathrm{O}\right) \delta: 1.21(3 \mathrm{H}, \mathrm{d}, J=6.0 \mathrm{~Hz}), 1.62-1.72(1 \mathrm{H}, \mathrm{m}), 1.91-1.99$ $(1 \mathrm{H}, \mathrm{m}), 3.47(1 \mathrm{H}, \mathrm{t}, J=6.0 \mathrm{~Hz}), 3.72-3.83(3 \mathrm{H}, \mathrm{m}), 3.97(1 \mathrm{H}$, quintet, $J=6.0 \mathrm{~Hz}) .{ }^{13} \mathrm{C}-\mathrm{NMR}\left(\mathrm{D}_{2} \mathrm{O}\right) \delta: 17.4,34.6,59.3,68.2,69.5,78.2$. HR-MS (FAB): Calcd for $\mathrm{C}_{6} \mathrm{H}_{15} \mathrm{O}_{4}\left(\mathrm{M}^{+}+1\right)$ : 151.0970 , Found: 151.0964

(2,3-anti, 3,4-anti)-3- ${ }^{t}$ Butyldimethylsilyloxy-4-hydroxy-2-p-methoxyphenoxy-6-heptene (26) and (2,3-anti,3,4-syn)-3- ${ }^{t}$ Butyldimethylsilyloxy-4-hydroxy-2-p-methoxyphenoxy-6-heptene (27) To a mixture of $( \pm)-10(1.547 \mathrm{~g}, 4.7 \mathrm{mmol})$ in THF $(30 \mathrm{ml}) / \mathrm{H}_{2} \mathrm{O}(30 \mathrm{ml})$ were added In powder $(3.2 \mathrm{~g}, 27.9 \mathrm{mmol})$ and allyl bromide $(1.7 \mathrm{~g}, 14.1 \mathrm{mmol})$ at $0{ }^{\circ} \mathrm{C}$ and the reaction mixture was stirred for $12 \mathrm{~h}$ at $\mathrm{rt}$. The reaction mixture was diluted with $\mathrm{H}_{2} \mathrm{O}$ and extracted with AcOEt. The organic layer was washed with brine and dried over $\mathrm{MgSO}_{4}$. Evaporation of the organic solvent gave a residue, which was chromatographed on silica gel $(150 \mathrm{~g}, n$ hexane : $\mathrm{AcOEt}=40: 1)$ to give $( \pm)-27(0.187 \mathrm{~g}, 11 \%)$ and $( \pm)-26(1.499 \mathrm{~g}$, $86 \%)$ as a colorless oil in elution order. $( \pm)-26$ : IR (neat): $3477 \mathrm{~cm}^{-1} ;{ }^{1} \mathrm{H}$ NMR $\delta: 0.07(3 \mathrm{H}, \mathrm{s}), 0.16(3 \mathrm{H}, \mathrm{s}), 0.93(9 \mathrm{H}, \mathrm{s}), 1.27(3 \mathrm{H}, \mathrm{d}, J=6.2 \mathrm{~Hz}), 1.98$ $(1 \mathrm{H}, \mathrm{brs}), 2.13-2.21(1 \mathrm{H}, \mathrm{m}), 2.48-2.54(1 \mathrm{H}, \mathrm{m}), 3.62-3.68(1 \mathrm{H}, \mathrm{m})$, $3.76(3 \mathrm{H}, \mathrm{s}), 3.80(1 \mathrm{H}, \mathrm{dd}, J=3.2,4.0 \mathrm{~Hz}), 4.56(1 \mathrm{H}, \mathrm{dq}, J=3.2,6.2 \mathrm{~Hz})$ $5.14-5.20(2 \mathrm{H}, \mathrm{m}), 5.80-5.90(1 \mathrm{H}, \mathrm{m}), 6.80-6.87(4 \mathrm{H}, \mathrm{m}) .{ }^{13} \mathrm{C}-\mathrm{NMR} \delta$ : $-4.7,-3.9,14.3,18.4,26.0$ (3C), 37.9, 55.7, 71.8, 74.2, 76.7, 114.7 (2C), 116.6 (2C), 118.5, 134.8, 151.6, 153.6. HR-MS (EI): Calcd for $\mathrm{C}_{20} \mathrm{H}_{34} \mathrm{O}_{8} \mathrm{Si}$ $\left(\mathrm{M}^{+}\right)$: 366.2226, Found: 366.2224. ( \pm )-27: IR (neat): $3547 \mathrm{~cm}^{-1} ;{ }^{1} \mathrm{H}-\mathrm{NMR}$ $\delta$ : $0.12(3 \mathrm{H}, \mathrm{s}), 0.17(3 \mathrm{H}, \mathrm{s}), 0.94(9 \mathrm{H}, \mathrm{s}), 1.26(3 \mathrm{H}, \mathrm{d}, J=6.2 \mathrm{~Hz}), 2.22-$ $2.36(2 \mathrm{H}, \mathrm{m}), 2.62(1 \mathrm{H}, \mathrm{d}, J=7.2 \mathrm{~Hz}), 3.66-3.67(1 \mathrm{H}, \mathrm{m}), 3.76(3 \mathrm{H}, \mathrm{s})$ $3.82(1 \mathrm{H}, \mathrm{dd}, J=3.6,4.4 \mathrm{~Hz}), 4.31(1 \mathrm{H}, \mathrm{dq}, J=4.4,6.2 \mathrm{~Hz}), 5.09-5.15(2 \mathrm{H}$, m), $5.84-5.94(1 \mathrm{H}, \mathrm{m}), 6.77-6.86(4 \mathrm{H}, \mathrm{m}) .{ }^{13} \mathrm{C}-\mathrm{NMR} \delta:-4.6,-3.8$ 15.0, 18.3, 26.0 (3C), 38.7, 55.6, 71.7, 76.20, 76.25, 114.7 (2C), 117.0 (2C), 117.2, 135.0, 151.2, 154.0. HR-MS (EI): Calcd for $\mathrm{C}_{20} \mathrm{H}_{34} \mathrm{O}_{8} \mathrm{Si}\left(\mathrm{M}^{+}\right)$: 366.2226, Found: 366.2227 .

$( \pm)$-Digitoxose $(3)$ i) To a solution of $( \pm)-26(1.97 \mathrm{~g}, 5.4 \mathrm{mmol})$ in THF $(20 \mathrm{ml})$ was added a $1.0 \mathrm{M}$ solution of TBAF in THF $(10.7 \mathrm{ml})$ and the reaction mixture was stirred for $1 \mathrm{~h}$ at $\mathrm{rt}$. The reaction mixture was diluted with $\mathrm{H}_{2} \mathrm{O}$ and extracted with AcOEt. The organic layer was washed with brine. The organic layer was dried over $\mathrm{MgSO}_{4}$ and evaporated to afford a residue. To a solution of the above residue in pyridine $(10 \mathrm{ml})$ were added a catalytic amount of DMAP and $\mathrm{Ac}_{2} \mathrm{O}(1.64 \mathrm{~g}, 16 \mathrm{mmol})$ and the reaction mixture was stirred for $15 \mathrm{~h}$ at rt. The reaction mixture was diluted with $\mathrm{H}_{2} \mathrm{O}$ and extracted with AcOEt. The organic layer was washed with $1 \mathrm{~m} \mathrm{HCl}$ solution and brine. The organic layer was dried over $\mathrm{MgSO}_{4}$ and evaporated to afford a residue, which was chromatographed on silica gel $(120 \mathrm{~g}, n$ hexane : $\mathrm{AcOEt}=40: 1)$ to give $( \pm)-\mathbf{2 8}(1.34 \mathrm{~g}, 74 \%)$ as a colorless oil. $( \pm)$ 28: IR (neat): $1743 \mathrm{~cm}^{-1} ;{ }^{1} \mathrm{H}-\mathrm{NMR} \delta: 1.30(3 \mathrm{H}, \mathrm{d}, J=6.2 \mathrm{~Hz}), 2.03(3 \mathrm{H}, \mathrm{s})$ $2.10(3 \mathrm{H}, \mathrm{s}), 2.32-2.40(1 \mathrm{H}, \mathrm{m}), 2.43-2.50(1 \mathrm{H}, \mathrm{m}), 3.76(3 \mathrm{H}, \mathrm{s}), 4.40$ $(1 \mathrm{H}, \mathrm{dq}, J=6.0,6.2 \mathrm{~Hz}), 5.02-5.08(2 \mathrm{H}, \mathrm{m}), 5.21-5.30(2 \mathrm{H}, \mathrm{m}), 5.66-$ $5.77(1 \mathrm{H}, \mathrm{m}), 6.80-6.86(4 \mathrm{H}, \mathrm{m}) .{ }^{13} \mathrm{C}-\mathrm{NMR} \delta: 16.0,20.92,20.98,34.5$, 55.6, 71.4, 73.7, 74.6, 114.7 (2C), $117.6(2 \mathrm{C}), 117.8,133.4,151.2,154.4$ 169.9, 170.1. HR-MS (EI): Calcd for $\mathrm{C}_{18} \mathrm{H}_{24} \mathrm{O}_{6}\left(\mathrm{M}^{+}\right)$: 336.1573 , Found: 336.1574. ii) To a solution of $( \pm)-\mathbf{2 8}(634 \mathrm{mg}, 1.88 \mathrm{mmol})$ in $\mathrm{MeCN}(5 \mathrm{ml})$ and $\mathrm{H}_{2} \mathrm{O}(2 \mathrm{ml})$ was added $\mathrm{CAN}(2.07 \mathrm{~g}, 3.77 \mathrm{mmol})$ at $\mathrm{rt}$ and the reaction mixture was stirred for $2 \mathrm{~h}$ at the same temperature. The reaction mixture was diluted with $\mathrm{H}_{2} \mathrm{O}$ and extracted with AcOEt. The organic layer was washed with brine and dried over $\mathrm{MgSO}_{4}$. Evaporation of the organic solvent gave a residue. To the above residue in $\mathrm{MeOH}(15 \mathrm{ml})$ was added $\mathrm{K}_{2} \mathrm{CO}_{3}(1.04 \mathrm{~g}, 7.5 \mathrm{mmol})$ and the reaction mixture was stirred for $1 \mathrm{~h}$ at $\mathrm{rt}$ The reaction mixture was filtered off and the filtrate was evaporated to afford a precipitate which was chromatographed on silica gel $(20 \mathrm{~g}, n-$ hexane : $\mathrm{AcOEt}=1: 1)$ to give $( \pm)-\mathbf{2 9}(202 \mathrm{mg}, 73 \%)$ as a colorless oil. $( \pm)$ 29: IR (neat): $3357 \mathrm{~cm}^{-1} ;{ }^{1} \mathrm{H}-\mathrm{NMR} \delta: 1.25(3 \mathrm{H}, \mathrm{d}, J=6.2 \mathrm{~Hz}), 2.23(1 \mathrm{H}, \mathrm{dt}$, $J=6.4,8.8 \mathrm{~Hz}), 2.54-2.60(1 \mathrm{H}, \mathrm{m}), 2.69(3 \mathrm{H}, \mathrm{br} \mathrm{s}), 3.44(1 \mathrm{H}, \mathrm{dd}, J=5.4$, $6.2 \mathrm{~Hz}), 3.70(1 \mathrm{H}, \mathrm{dt}, J=3.6,7.2 \mathrm{~Hz}), 3.97(1 \mathrm{H}$, quintet, $J=6.2 \mathrm{~Hz}), 5.17-$
$5.22(2 \mathrm{H}, \mathrm{m}), 5.83-5.93(1 \mathrm{H}, \mathrm{m}) .{ }^{13} \mathrm{C}-\mathrm{NMR} \delta: 18.3,37.9,69.3,71.9,76.5$ 118.8, 134.4. HR-MS (FAB): Calcd for $\mathrm{C}_{7} \mathrm{H}_{15} \mathrm{O}_{3}\left(\mathrm{M}^{+}+1\right)$ : 147.1021 , Found: 147.1022. iii) Ozone was passed through a solution of $( \pm)-29(275 \mathrm{mg}$, $1.88 \mathrm{mmol})$ in $\mathrm{MeOH}(20 \mathrm{ml})$ for $0.5 \mathrm{~h}$ at $-20^{\circ} \mathrm{C}$ then $\mathrm{Me}_{2} \mathrm{~S}(1 \mathrm{ml})$ was added to the ozonolyzed product. The reaction mixture was stirred for $1 \mathrm{~h}$ at $\mathrm{rt}$ and evaporated to give a precipitate which was chromatographed on silica gel $\left(20 \mathrm{~g}, \mathrm{CHCl}_{3}: \mathrm{MeOH}=10: 1\right)$ to give a $3.9: 1$ diastereomeric mixture of $( \pm)$-digitoxose $(3)(202 \mathrm{mg}, 73 \%)$ as a colorless solide. ( \pm )-3: HR-MS (FAB): Calcd for $\mathrm{C}_{6} \mathrm{H}_{13} \mathrm{O}_{4}\left(\mathrm{M}^{+}+1\right)$ : 149.0814, Found: 149.0816; ${ }^{1} \mathrm{H}-\mathrm{NMR}$ $\left(\beta\right.$-anomer, major, $\left.\mathrm{D}_{2} \mathrm{O}\right) \delta: 1.04(3 \mathrm{H}, \mathrm{d}, J=6.0 \mathrm{~Hz}), 1.49-1.55(1 \mathrm{H}, \mathrm{m})$, $1.85(1 \mathrm{H}$, ddd $J=2.4,3.6,14.4 \mathrm{~Hz}), 3.12(1 \mathrm{H}, \mathrm{dd}, J=3.2,10.0 \mathrm{~Hz}), 3.61-$ $3.69(1 \mathrm{H}, \mathrm{m}), 3.92-3.96(1 \mathrm{H}, \mathrm{m}), 4.91(1 \mathrm{H}, \mathrm{dd}, J=2.0,10.0 \mathrm{~Hz}) .{ }^{13} \mathrm{C}-\mathrm{NMR}$ $\left(\mathrm{D}_{2} \mathrm{O}\right) \delta: 18.1,39.4,68.1,70.1,73.0,92.1 .{ }^{1} \mathrm{H}-\mathrm{NMR}(\alpha$-anomer, minor, $\left.\mathrm{D}_{2} \mathrm{O}\right) \delta: 0.99(3 \mathrm{H}, \mathrm{d}, J=6.8 \mathrm{~Hz}), 1.67-1.71(1 \mathrm{H}, \mathrm{m}), 1.88-1.90(1 \mathrm{H}, \mathrm{m})$ $3.21(1 \mathrm{H}, \mathrm{dd}, J=3.1,8.8 \mathrm{~Hz}), 3.61-3.68(1 \mathrm{H}, \mathrm{m}), 3.90-3.96(1 \mathrm{H}, \mathrm{m}), 4.97$ $(1 \mathrm{H}, \mathrm{t}, J=2.8 \mathrm{~Hz}) .{ }^{13} \mathrm{C}-\mathrm{NMR}\left(\mathrm{D}_{2} \mathrm{O}\right) \delta: 18.0,39.0,65.8,70.7,72.5,91.5$.

$( \pm)$-Olivose (4) i) To a solution of $( \pm)-27(660 \mathrm{mg}, 1.8 \mathrm{mmol})$ in THF $(10 \mathrm{ml})$ was added a $1.0 \mathrm{M}$ solution of TBAF in THF $(4 \mathrm{ml})$ and the reaction mixture was stirred for $1 \mathrm{~h}$ at $\mathrm{rt}$. The reaction mixture was worked up in the same way as ( \pm )-28 to afford a residue. To a solution of the above residue in pyridine $(10 \mathrm{ml})$ were added a catalytic amount of DMAP and $\mathrm{Ac}_{2} \mathrm{O}$ $(550 \mathrm{mg}, 5.3 \mathrm{mmol})$ and the reaction mixture was stirred for $15 \mathrm{~h}$ at $\mathrm{rt}$. The reaction mixture was worked up in the same way as $( \pm)-28$ to give $( \pm)-30$ (460 mg, 76\%) as a colorless oil. ( \pm )-30: IR (neat): $1744 \mathrm{~cm}^{-1} ;{ }^{1} \mathrm{H}-\mathrm{NMR} \delta$ : $1.26(3 \mathrm{H}, \mathrm{d}, J=6.4 \mathrm{~Hz}), 1.94(3 \mathrm{H}, \mathrm{s}), 2.15(3 \mathrm{H}, \mathrm{s}), 2.32(2 \mathrm{H}, \mathrm{t}, J=7.0 \mathrm{~Hz})$, $3.75(3 \mathrm{H}, \mathrm{s}), 4.31(1 \mathrm{H}$, quintet, $J=6.4 \mathrm{~Hz}), 5.06-5.11(2 \mathrm{H}, \mathrm{m}), 5.18-5.20$ $(1 \mathrm{H}, \mathrm{m}), 5.32-5.36(1 \mathrm{H}, \mathrm{m}), 5.70-5.80(1 \mathrm{H}, \mathrm{m}), 6.77-6.84(4 \mathrm{H}, \mathrm{m}) .{ }^{13} \mathrm{C}-$ NMR $\delta: 16.1,20.78,20.83,35.6,55.6,70.773 .3,74.5,114.6(2 \mathrm{C}), 117.6$ (2C), 118.4, 132.6, 151.2, 154.4, 170.0, 170.1. HR-MS (FAB): Calcd for $\mathrm{C}_{18} \mathrm{H}_{25} \mathrm{O}_{6}\left(\mathrm{M}^{+}+1\right): 337.1652$, Found: 337.1634 . ii) To a solution of $( \pm)-\mathbf{3 0}$ $(383 \mathrm{mg}, 1.13 \mathrm{mmol})$ in $\mathrm{MeCN}(4 \mathrm{ml})$ and $\mathrm{H}_{2} \mathrm{O}(1 \mathrm{ml})$ was added CAN $(1.24 \mathrm{~g}, 2.26 \mathrm{mmol})$ at $\mathrm{rt}$ and the reaction mixture was stirred for $2 \mathrm{~h}$ at the same temperature. The reaction mixture was worked up in the same way as $( \pm)-29$ to give a residue. To the above residue in $\mathrm{MeOH}(5 \mathrm{ml})$ was added $\mathrm{K}_{2} \mathrm{CO}_{3}(620 \mathrm{mg}, 4.5 \mathrm{mmol})$ and the reaction mixture was stirred for $1 \mathrm{~h}$ at $\mathrm{rt}$. The reaction mixture was worked up in the same way as $( \pm)$-29 to give $( \pm)$ $31(120 \mathrm{mg}, 72 \%)$ as a colorless oil. ( \pm )-27: IR (neat): $3357 \mathrm{~cm}^{-1} ;{ }^{1} \mathrm{H}-\mathrm{NMR}$ $\delta: 1.22(3 \mathrm{H}, \mathrm{d}, J=6.8 \mathrm{~Hz}), 2.29-2.23(2 \mathrm{H}, \mathrm{m}), 3.32(1 \mathrm{H}, \mathrm{dd}, J=2.4$, $4.0 \mathrm{~Hz}), 3.48(3 \mathrm{H}, \mathrm{brs}), 3.87-3.94(2 \mathrm{H}, \mathrm{m}), 5.09-5.16(2 \mathrm{H}, \mathrm{m}), 5.77-$ $5.87(1 \mathrm{H}, \mathrm{m}) .{ }^{13} \mathrm{C}-\mathrm{NMR} \delta: 18.8,38.1,69.9,70.0,75.1,118.8,134.3$. HRMS (FAB): Calcd for $\mathrm{C}_{7} \mathrm{H}_{15} \mathrm{O}_{3}\left(\mathrm{M}^{+}+1\right)$ : 147.1021, Found: 147.1030. iii) Ozone was passed through a solution of $( \pm)-31(275 \mathrm{mg}, 1.88 \mathrm{mmol})$ in $\mathrm{MeOH}(30 \mathrm{ml})$ for $0.5 \mathrm{~h}$ at $-20{ }^{\circ} \mathrm{C}$ then $\mathrm{Me}_{2} \mathrm{~S}(1 \mathrm{ml})$ was added to the ozonolyzed product. The reaction mixture was stirred for $1 \mathrm{~h}$ at rt. The reaction mixture was worked up in the same way as $( \pm)-3$ to give a $4: 3$ diastereomeric mixture of $( \pm)$-olivose $(4)(202 \mathrm{mg}, 73 \%)$ as a colorless solid. $( \pm)-4$ HR-MS (FAB): Calcd for $\mathrm{C}_{6} \mathrm{H}_{13} \mathrm{O}_{4}\left(\mathrm{M}^{+}+1\right)$ : 149.0814, Found: 149.0796; ${ }^{1} \mathrm{H}-\mathrm{NMR}\left(\beta\right.$-anomer, major, $\left.\mathrm{D}_{2} \mathrm{O}\right) \delta: 1.04(3 \mathrm{H}, \mathrm{d}, J=6.2 \mathrm{~Hz}), 1.25(1 \mathrm{H}, \mathrm{dt}$, $J=10.0,12.0 \mathrm{~Hz}), 2.01(1 \mathrm{H}$, ddd, $J=2.0,5.2,12.0 \mathrm{~Hz}), 2.81(1 \mathrm{H}, \mathrm{t}$, $J=10.0 \mathrm{~Hz}), 3.17(1 \mathrm{H}, \mathrm{dt}, J=6.2,9.0 \mathrm{~Hz}), 3.42(1 \mathrm{H}, \mathrm{ddd}, J=5.2,9.0$ $12.0 \mathrm{~Hz}), 4.66(1 \mathrm{H}, \mathrm{dd}, J=2.0,10.0 \mathrm{~Hz}) .{ }^{13} \mathrm{C}-\mathrm{NMR}\left(\mathrm{D}_{2} \mathrm{O}\right) \delta: 17.7,40.5$, $68.5,68.6,77.0,93.9 .{ }^{1} \mathrm{H}-\mathrm{NMR}\left(\alpha\right.$-anomer, minor, $\left.\mathrm{D}_{2} \mathrm{O}\right) \delta: 1.02(3 \mathrm{H}, \mathrm{d}$, $J=6.2 \mathrm{~Hz}), 1.46(1 \mathrm{H}, \mathrm{ddd}, J=3.6,12.0,13.2 \mathrm{~Hz}), 1.88(1 \mathrm{H}, \mathrm{ddd}, J=1.0,5.2$, $13.2 \mathrm{~Hz}), 2.86(1 \mathrm{H}, \mathrm{t}, J=9.2 \mathrm{~Hz}), 3.58-3.67(2 \mathrm{H}, \mathrm{m}), 5.07(1 \mathrm{H}, \mathrm{d}$ $J=3.6 \mathrm{~Hz}){ }^{13} \mathrm{C}-\mathrm{NMR}\left(\mathrm{D}_{2} \mathrm{O}\right) \delta: 17.7,38.3,70.9,72.6,77.6,91.9$.

(2,3-syn, 3,4-anti)-3,4-Diacetoxy-2-p-methoxyphenoxy-6-heptene (34) and (2,3-syn, 3,4-syn)-3,4-Diacetoxy-2-p-methoxy-phenoxy-6-heptene (35) i) To a mixture of $( \pm)-\mathbf{1 4}(193 \mathrm{mg}, 0.59 \mathrm{mmol})$ in THF $(3 \mathrm{ml}) / \mathrm{H}_{2} \mathrm{O}(3 \mathrm{ml})$ were added In powder $(300 \mathrm{mg}, 2.6 \mathrm{mmol})$ and allyl bromide $(170 \mathrm{mg}$, $1.4 \mathrm{mmol}$ ) at $0{ }^{\circ} \mathrm{C}$ and the reaction mixture was stirred for $12 \mathrm{~h}$ at $\mathrm{rt}$. The reaction mixture was worked up in the same way as ( \pm )-26 and ( \pm )-27 to give a ca. $1: 1$ mixture $(218 \mathrm{mg}, 99 \%)$ of $( \pm)-\mathbf{3 2}$ and $( \pm)-\mathbf{3 3}$ as a colorless oil. HR-MS (EI): Calcd for $\mathrm{C}_{20} \mathrm{H}_{34} \mathrm{O}_{8} \mathrm{Si}\left(\mathrm{M}^{+}\right)$: 366.2226 , Found: 366.2223. ii) To a solution of the above mixture $(218 \mathrm{mg}, 0.59 \mathrm{mmol})$ in THF $(2 \mathrm{ml})$ was added a $1.0 \mathrm{M}$ solution of TBAF in THF $(1.5 \mathrm{ml})$ and the reaction mixture was stirred for $1 \mathrm{~h}$ at $\mathrm{rt}$. The reaction mixture was worked up in the same way as ( \pm )-28 to afford a residue. To a solution of the above residue in pyridine $(4 \mathrm{ml})$ were added a catalytic amount of DMAP and $\mathrm{Ac}_{2} \mathrm{O}(242 \mathrm{mg}$, $2.3 \mathrm{mmol}$ ) and the reaction mixture was stirred for $15 \mathrm{~h}$ at $\mathrm{rt}$. The reaction mixture was worked up in the same way as $( \pm)$-28 to give ( \pm )-35 (less polar, $74 \mathrm{mg}, 37 \%$ ) and ( \pm )-34 (more polar, $76 \mathrm{mg}, 38 \%$ ) as a colorless oil (土)-34: IR (neat): $1742 \mathrm{~cm}^{-1}$; ${ }^{1} \mathrm{H}-\mathrm{NMR} \delta: 1.27(3 \mathrm{H}, \mathrm{d}, J=6.4 \mathrm{~Hz}), 1.90$ $(3 \mathrm{H}, \mathrm{s}), 2.11(3 \mathrm{H}, \mathrm{s}), 2.32-2.39(1 \mathrm{H}, \mathrm{m}), 2.46-2.52(1 \mathrm{H}, \mathrm{m}), 3.76(3 \mathrm{H}, \mathrm{s})$, $4.40(1 \mathrm{H}, \mathrm{dq}, J=4.0,6.4 \mathrm{~Hz}), 5.04-5.10(2 \mathrm{H}, \mathrm{m}), 5.19-5.24(2 \mathrm{H}, \mathrm{m})$, 
$5.70-5.80(1 \mathrm{H}, \mathrm{m}), 6.79-6.90(4 \mathrm{H}, \mathrm{m}) .{ }^{13} \mathrm{C}-\mathrm{NMR} \delta: 16.1,20.8,20.9$, 34.6, 55.7, 71.0, 73.8, 75.1, 114.7 (2C), 117.5 (2C), 118.0, 133.1, 151.9, 154.3, 169.9, 170.3. HR-MS (EI): Calcd for $\mathrm{C}_{18} \mathrm{H}_{24} \mathrm{O}_{6}\left(\mathrm{M}^{+}\right): 336.1573$, Found: 336.1581. ( \pm )-35: IR (neat): $1742 \mathrm{~cm}^{-1} ;{ }^{1} \mathrm{H}-\mathrm{NMR} \delta: 1.23(3 \mathrm{H}, \mathrm{d}$ $J=6.2 \mathrm{~Hz}), 2.03(6 \mathrm{H}, \mathrm{s}), 2.18-2.40(2 \mathrm{H}, \mathrm{m}), 3.73(3 \mathrm{H}, \mathrm{s}), 4.33(1 \mathrm{H}$, quintet $J=6.2 \mathrm{~Hz}), 5.02-5.08(2 \mathrm{H}, \mathrm{m}), 5.18(1 \mathrm{H}, \mathrm{dd}, J=4.8,6.2 \mathrm{~Hz}), 5.27(1 \mathrm{H}, \mathrm{dt}$, $J=4.8,7.2 \mathrm{~Hz}), 5.66-5.74(1 \mathrm{H}, \mathrm{m}), 6.77-6.84(4 \mathrm{H}, \mathrm{m}) .{ }^{13} \mathrm{C}-\mathrm{NMR} \delta: 16.0$ 20.7, 20.9, 35.6, 55.6, 71.2, 73.8, 75.2, 114.6 (2C), 117.2 (2C), 118.5, 132.5, 151.7, 154.2, 170.2, 170.4. HR-MS (EI): Calcd for $\mathrm{C}_{18} \mathrm{H}_{24} \mathrm{O}_{6}\left(\mathrm{M}^{+}\right)$: 336.1573, Found: 336.1572

$( \pm)$-Oliose (5) i) To a solution of $( \pm)-34(54 \mathrm{mg}, 0.16 \mathrm{mmol})$ in $\mathrm{MeCN}$ $(4 \mathrm{ml})$ and $\mathrm{H}_{2} \mathrm{O}(1 \mathrm{ml})$ was added CAN $(170 \mathrm{~g}, 0.31 \mathrm{mmol})$ at $\mathrm{rt}$ and the reaction mixture was stirred for $2 \mathrm{~h}$ at the same temperature. The reaction mixture was worked in the same way as ( \pm )-29 to give a residue. To the above residue in $\mathrm{MeOH}(3 \mathrm{ml})$ was added $\mathrm{K}_{2} \mathrm{CO}_{3}(80 \mathrm{mg}, 0.58 \mathrm{mmol})$ and the reaction mixture was stirred for $1 \mathrm{~h}$ at $\mathrm{rt}$. The reaction mixture was worked up in the same way as $( \pm)-\mathbf{2 9}$ to give $( \pm)-\mathbf{3 6}(18 \mathrm{mg}, 76 \%)$ as a colorless oil. $( \pm)$ 36: IR (neat): $3357 \mathrm{~cm}^{-1} ;{ }^{1} \mathrm{H}-\mathrm{NMR} \delta: 1.22(3 \mathrm{H}, \mathrm{d}, J=6.4 \mathrm{~Hz}), 2.23-2.38$ $(2 \mathrm{H}, \mathrm{m}), 3.00(3 \mathrm{H}, \mathrm{br} \mathrm{s}), 3.29(1 \mathrm{H}, \mathrm{dd}, J=2.9,4.4 \mathrm{~Hz}), 3.77(1 \mathrm{H}, \mathrm{dt}, J=4.4$, $8.4 \mathrm{~Hz}), 4.05(1 \mathrm{H}, \mathrm{dq}, J=2.9,6.4 \mathrm{~Hz}), 5.14-5.19(2 \mathrm{H}, \mathrm{m}), 5.77-5.87(1 \mathrm{H}$, m). ${ }^{13} \mathrm{C}-\mathrm{NMR} \delta: 19.5,36.6,66.8,72.8,75.9,118.3,134.4$. HR-MS (FAB): Calcd for $\mathrm{C}_{7} \mathrm{H}_{15} \mathrm{O}_{3}\left(\mathrm{M}^{+}+1\right)$ : 147.1021, Found: 147.0985. ii) Ozone was passed through a solution of $( \pm)-\mathbf{3 6}(46 \mathrm{mg}, 0.31 \mathrm{mmol})$ in $\mathrm{MeOH}(4 \mathrm{ml})$ for $0.5 \mathrm{~h}$ at $-20^{\circ} \mathrm{C}$ then $\mathrm{Me}_{2} \mathrm{~S}(1 \mathrm{ml})$ was added to the ozonolyzed product. The reaction mixture was stirred for $1 \mathrm{~h}$ at $\mathrm{rt}$. The reaction mixture was worked up in the same way as $( \pm)$-3 to give a $1: 1$ diastereomeric mixture of $( \pm)$ oliose $(5)(31 \mathrm{mg}, 66 \%)$ as a colorless solid. ( \pm )-5: HR-MS (FAB): Calcd for $\mathrm{C}_{6} \mathrm{H}_{13} \mathrm{O}_{4}\left(\mathrm{M}^{+}+1\right)$ : 149.0814 , Found: 149.0861 ; ${ }^{1} \mathrm{H}-\mathrm{NMR}(\beta$-anomer $\left.\mathrm{D}_{2} \mathrm{O}\right) \delta: 1.02(3 \mathrm{H}, \mathrm{d}, J=6.8 \mathrm{~Hz}), 1.39(1 \mathrm{H}, \mathrm{dt}, J=10.0,12.0 \mathrm{~Hz}), 1.60-1.63$ $(1 \mathrm{H}, \mathrm{m}), 3.32(1 \mathrm{H}, \mathrm{brs}), 3.44(1 \mathrm{H}$, br q, $J=0.8,6.6 \mathrm{~Hz}), 3.64(1 \mathrm{H}, \mathrm{ddd}$ $J=3.2,4.8,12.4 \mathrm{~Hz}), 4.58(1 \mathrm{H}, \mathrm{dd}, J=2.4,10.0 \mathrm{~Hz}) .{ }^{13} \mathrm{C}-\mathrm{NMR}\left(\mathrm{D}_{2} \mathrm{O}\right) \delta$ $16.8,35.3,68.8,70.1,71.5,94.3 .{ }^{1} \mathrm{H}-\mathrm{NMR}\left(\alpha\right.$-anomer, $\left.\mathrm{D}_{2} \mathrm{O}\right) \delta: 0.98(3 \mathrm{H}, \mathrm{d}$ $J=6.4 \mathrm{~Hz}), 1.53-1.58(1 \mathrm{H}, \mathrm{m}), 1.73-1.79(1 \mathrm{H}, \mathrm{m}), 3.46(1 \mathrm{H}, \mathrm{br} \mathrm{s}), 3.86$ $(1 \mathrm{H}$, ddd, $J=2.8,5.2,11.6 \mathrm{~Hz}), 3.91(1 \mathrm{H}, \mathrm{br} \mathrm{q}, J=6.4 \mathrm{~Hz}), 5.12(1 \mathrm{H}, \mathrm{br} \mathrm{s})$ ${ }^{13} \mathrm{C}-\mathrm{NMR}\left(\mathrm{D}_{2} \mathrm{O}\right) \delta: 16.6,32.3,65.5,67.2,71.2,92.1$.

$( \pm)$-Boivinose (6) i) To a solution of $( \pm)-35(47 \mathrm{mg}, 0.14 \mathrm{mmol})$ in $\mathrm{MeCN}(4 \mathrm{ml})$ and $\mathrm{H}_{2} \mathrm{O}(1 \mathrm{ml})$ was added CAN $(150 \mathrm{mg}, 0.27 \mathrm{mmol})$ at $\mathrm{rt}$ and the reaction mixture was stirred for $2 \mathrm{~h}$ at the same temperature. The reaction mixture was worked in the same way as $( \pm)-29$ to give a residue. To the above residue in $\mathrm{MeOH}(3 \mathrm{ml})$ was added $\mathrm{K}_{2} \mathrm{CO}_{3}(80 \mathrm{mg}, 0.58 \mathrm{mmol})$ and the reaction mixture was stirred for $1 \mathrm{~h}$ at rt. The reaction mixture was worked up in the same way as ( \pm )-29 to give ( \pm$)-\mathbf{3 7}(16 \mathrm{mg}, 78 \%)$ as a colorless oil. ( \pm )-37: IR (neat): $3357 \mathrm{~cm}^{-1} ;{ }^{1} \mathrm{H}-\mathrm{NMR} \delta: 1.14(3 \mathrm{H}, \mathrm{d}, J=$ $6.4 \mathrm{~Hz}), 2.27(2 \mathrm{H}, \mathrm{t}, J=6.6 \mathrm{~Hz}), 2.96(3 \mathrm{H}, \mathrm{brs}), 3.14(1 \mathrm{H}, \mathrm{dd}, J=2.4$, $3.6 \mathrm{~Hz}), 3.65(1 \mathrm{H}, \mathrm{dt}, J=2.4,6.6 \mathrm{~Hz}), 3.82(1 \mathrm{H}, \mathrm{dq}, J=3.6,6.4 \mathrm{~Hz}), 5.02$ $5.08(2 \mathrm{H}, \mathrm{m}), 5.67-5.77(1 \mathrm{H}, \mathrm{m}) .{ }^{13} \mathrm{C}-\mathrm{NMR} \delta: 19.8,38.7,69.8,72.6,75.4$ 118.5, 134.2. HR-MS (FAB): Calcd for $\mathrm{C}_{7} \mathrm{H}_{15} \mathrm{O}_{3}\left(\mathrm{M}^{+}+1\right)$ : 147.1021 , Found: 147.1039. ii) Ozone was passed through a solution of $( \pm)-37(40 \mathrm{mg}$, $0.28 \mathrm{mmol})$ in $\mathrm{MeOH}(4 \mathrm{ml})$ for $0.5 \mathrm{~h}$ at $-20^{\circ} \mathrm{C}$ then $\mathrm{Me}_{2} \mathrm{~S}(1 \mathrm{ml})$ was added to the ozonolyzed product. The reaction mixture was stirred for $1 \mathrm{~h}$ at $\mathrm{rt}$. The reaction mixture was worked up in the same way as ( \pm )-3 to give ( \pm )-boivinose $(6)(33 \mathrm{mg}, 81 \%)$ as a colorless solid. $( \pm)-6$ : HR-MS (FAB): Calcd for $\mathrm{C}_{6} \mathrm{H}_{13} \mathrm{O}_{4}\left(\mathrm{M}^{+}+1\right)$ : 149.0814, Found: $149.0807 ;{ }^{1} \mathrm{H}-\mathrm{NMR}\left(\beta\right.$-anomer, $\left.\mathrm{D}_{2} \mathrm{O}\right)$ $\delta: 1.00(3 \mathrm{H}, \mathrm{d}, J=6.8 \mathrm{~Hz}), 1.47(1 \mathrm{H}, \mathrm{dt}, J=3.1,13.2 \mathrm{~Hz}), 1.58(1 \mathrm{H}, \mathrm{ddd}$, $J=3.3,9.8,12.9 \mathrm{~Hz}), 3.03-3.05(1 \mathrm{H}, \mathrm{m}), 3.61-3.65(1 \mathrm{H}, \mathrm{m}), 3.68(1 \mathrm{H}$, br q, $J=6.2 \mathrm{~Hz}), 4.78(1 \mathrm{H}, \mathrm{dd}, J=4.5,7.4 \mathrm{~Hz}) \cdot{ }^{13} \mathrm{C}-\mathrm{NMR}\left(\mathrm{D}_{2} \mathrm{O}\right) \delta: 16.7$, $34.7,69.4,69.9(2 \mathrm{C}), 92.7$

Formal Synthesis of $( \pm)$-Olivose (4) i) To a mixture of $( \pm)-16$ $(286 \mathrm{mg}, 1.2 \mathrm{mmol})$ in THF $(3 \mathrm{ml}) / \mathrm{H}_{2} \mathrm{O}(3 \mathrm{ml})$ were added $\mathrm{In}$ powder $(550 \mathrm{mg}, 4.8 \mathrm{mmol})$ and allyl bromide $(300 \mathrm{mg}, 2.48 \mathrm{mmol})$ at $0{ }^{\circ} \mathrm{C}$ and the reaction mixture was stirred for $12 \mathrm{~h}$ at $\mathrm{rt}$. The reaction mixture was worked up in the same way as ( \pm -26 and ( \pm )-27 to give a $c a .8: 1$ mixture (336 mg, 93\%) of ( \pm )-38 and ( \pm )-39 as a colorless oil. ( \pm )-38 (major): IR (neat): $3460 \mathrm{~cm}^{-1}$; ${ }^{1} \mathrm{H}-\mathrm{NMR} \delta$ : $0.13(3 \mathrm{H}, \mathrm{s}), 0.18(3 \mathrm{H}, \mathrm{s}), 0.93(9 \mathrm{H}, \mathrm{s}), 1.51(3 \mathrm{H}, \mathrm{d}$
$J=6.8 \mathrm{~Hz}), 1.93(1 \mathrm{H}, \mathrm{d}, J=3.6 \mathrm{~Hz}), 2.15-2.23(1 \mathrm{H}, \mathrm{m}), 2.39-2.45(1 \mathrm{H}$, m), $3.71-3.76(1 \mathrm{H}, \mathrm{m}), 3.79(1 \mathrm{H}, \mathrm{dd}, J=3.8,5.2 \mathrm{~Hz}), 4.26(1 \mathrm{H}, \mathrm{dq}, J=3.8$, $6.8 \mathrm{~Hz}), 5.10-5.21(2 \mathrm{H}, \mathrm{m}), 5.79-5.89(1 \mathrm{H}, \mathrm{m}) .{ }^{13} \mathrm{C}-\mathrm{NMR} \delta:-4.2,-4.0$, 18.4, 20.0, 26.0 (3C), 37.2, 58.1, 71.9, 79.1, 118.7, 134.4. HR-MS (FAB): Calcd for $\mathrm{C}_{13} \mathrm{H}_{28} \mathrm{O}_{2} \mathrm{ClSi}\left(\mathrm{M}^{+}+1\right)$ : 279.1547, Found: 279.1571 . ii) To a solution of the above $8: 1$ mixture $(336 \mathrm{mg}, 1.2 \mathrm{mmol})$ in $\mathrm{CH}_{2} \mathrm{Cl}_{2}(3 \mathrm{ml})$ were added ethyl vinyl ether $(87 \mathrm{mg}, 1.2 \mathrm{mmol}$ ) and a catalytic amount of pyridinum $p$-toluenesufonate (PPTS) at $\mathrm{rt}$ and the reaction mixture was stirred for $3 \mathrm{~h}$ at the same temperature. The reaction mixture was diluted with $\mathrm{H}_{2} \mathrm{O}$ and extracted with AcOEt. The organic layer was washed with brine and dried over $\mathrm{MgSO}_{4}$. Evaporation of the organic solvent gave a crude tetrahydropyramyl (THP) ether. To a solution of THP ether in THF $(5 \mathrm{ml})$ was added $1 \mathrm{M}$ solution of tetrabutylammonium fluoride (TBAF) in THF $(2.4 \mathrm{ml}, 2.4 \mathrm{mmol})$ at $\mathrm{rt}$ and the reaction mixture was stirred for $2 \mathrm{~h}$ at the same temperature. The reaction mixture was evaporated to give a residue. A mixture of the above residue in $\mathrm{MeOH}(5 \mathrm{ml})$ and $\mathrm{K}_{2} \mathrm{CO}_{3}(166 \mathrm{mg}, 1.2 \mathrm{mmol})$ was stirred for $1 \mathrm{~h}$ at $\mathrm{rt}$ and the reaction mixture was diluted with $\mathrm{H}_{2} \mathrm{O}$ and extracted with AcOEt. The organic layer was washed with brine and dried over $\mathrm{MgSO}_{4}$. Evaporation of the organic solvent gave a crude oil. A solution of the crude oil in THF $(2.5 \mathrm{ml}) / \mathrm{H}_{2} \mathrm{O}(2.5 \mathrm{ml})$ and $\mathrm{AcOH}(2 \mathrm{ml})$ was stirred for $5 \mathrm{~h}$ at $\mathrm{rt}$. The reaction mixture was diluted with saturated $\mathrm{NaHCO}_{3}$ solution and extracted with AcOEt. The organic layer was washed with brine and dried over $\mathrm{MgSO}_{4}$. Evaporation of the organic solvent gave a residue, which was chromatographed on silica gel $(10 \mathrm{~g}, n$-hexane : $\mathrm{AcOEt}=10: 1)$ to give $( \pm)-40(27 \mathrm{mg}, 17 \%$ in 4 steps $)$ as a colorless oil. ( \pm )-40: IR (neat): $3448 \mathrm{~cm}^{-1}$; ${ }^{1} \mathrm{H}-\mathrm{NMR} \delta: 1.30(3 \mathrm{H}, \mathrm{d}, J=5.2 \mathrm{~Hz}), 1.97(1 \mathrm{H}, \mathrm{dd}, J=2.2 \mathrm{~Hz})$, $2.24-2.32(1 \mathrm{H}, \mathrm{m}), 2.36-2.42(1 \mathrm{H}, \mathrm{m}), 2.72(1 \mathrm{H}, \mathrm{dd}, J=2.2,4.0 \mathrm{~Hz}), 3.05$ $(1 \mathrm{H}, \mathrm{dq}, J=2.2,5.2 \mathrm{~Hz}), 3.77(1 \mathrm{H}, \mathrm{dt}, J=4.0,6.4 \mathrm{~Hz}), 5.10-5.17(2 \mathrm{H}, \mathrm{m})$, $5.79-5.89(1 \mathrm{H}, \mathrm{m}){ }^{13} \mathrm{C}-\mathrm{NMR} \delta: 17.2,38.1,51.5,61.3,68.3,118.2,133.6$. HR-MS (FAB): Calcd for $\mathrm{C}_{7} \mathrm{H}_{13} \mathrm{O}_{2}\left(\mathrm{M}^{+}+1\right)$ : 129.0916 , Found: 129.0921

\section{References}

1) Akita H., Matsukura H., Oishi T., Tetrahedron Lett., 27, 5397—5400 (1986).

2) Akita H., Kawaguchi T., Enoki Y., Oishi T., Chem. Pharm. Bull., 38, $323-328$ (1990).

3) Kato K., Nishimura A., Yamamoto Y., Akita H., Tetrahedron Lett., 43, $643-645$ (2002).

4) Kato K., Ono M., Akita H., Tetrahedron:Asymm., 8, 2295-2298 (1997).

5) Akaike H., Horie H., Kato K., Akita H., Tetrahedron:Asymm., 19, 1100-1105 (2008)

6) Argoudelis A. D., Zieserl J. Z., Tetrhedron Lett., 1966, 1969-1973 (1966).

7) Fukuyama K., Katsube Y., Noda A., Hamasaki T., Hatsuda Y., Bull. Chem. Soc. Jpn., 51, 3175-3181 (1978).

8) Valverde S., Herradon B., Rabanal R. M., Martin-Lomas M., Can. J. Chem., 65, 339-342 (1986)

9) Hiraoka H., Furuta K., Ikeda N., Yamamoto H., Bull. Chem. Soc. Jpn., 57, 2777-2780 (1984)

10) Murayama T., Sugiyama T., Yamashita K., Agric. Biol. Chem., 51, 2055-2060 (1987)

11) Schlessinger R. H., Gillman K. W., Tetrahedron Lett., 40, 1257-1260 (1999).

12) Honda T., Sano N., Kanai K., Heterocycles, 41, 425-429 (1995).

13) Yang Z.-C., Zhou W.-S., Tetrahedron Lett., 36, 5617-5618 (1995).

14) Lewis D., J. Chem. Soc., Perkin Trans. 2, 1990, 1349-1351 (1990).

15) Binder W. H., Prenner R. H., Schmid, W., Tetrahedron, 50, 749-758 (1994).

16) Paquette L. A., Mitzel T. M., Tetrahedron Lett., 36, 6863-6866 (1995).

17) Roush W. R., Brown R. J., J. Org. Chem., 48, 5093-5101 (1983).

18) Paquette L. A., Mitzel T. M., J. Am. Chem. Soc., 118, 1931-1937 (1996). 